\title{
Analysis of the efficiency of strengthening design models for reinforced concrete columns
}

\section{Análise da eficiência de modelos para dimensionamento do reforço em pilares de concreto armado}

P. C. RODRIGUES a

patriciarodgs@gmail.com

D. L. ARAÚJO a

dlaraujo@ufg.br

\begin{abstract}
This paper develops a comparative analysis of the main design models used for predicting the strengthening of reinforced concrete columns subjected to uniaxial compression. The study evaluated four strengthening design models with concrete jackets and eleven strengthening design models with wrapping in Carbon Fiber-Reinforced Polymer (CFRP). All models consider the effect of confinement provided by the transverse steel reinforcement and the CFRP sheet wrapping on the gain in resistance of the column. For the validation, a database was formulated containing 135 experimental results of columns tested by several researches, which was used to analyze all design models and identify which was best for expressing the behavior of the strengthened column. At the end of the study, one confinement design model with transverse reinforcement and eleven design models with confinement provided by CFRP sheet wrapping and transverse steel reinforcement which showed the best resistance predictions were selected.
\end{abstract}

Keywords: strengthening, confinement, carbon fibers, concrete jacketing, design models.

\section{Resumo}

Este trabalho desenvolve uma avaliação comparativa dos principais modelos empíricos de dimensionamento utilizados no reforço de pilares de concreto armado submetidos a carregamento axial centrado. Foram avaliados quatro modelos de confinamento por armaduras transversais, utilizados no dimensionamento do reforço por aumento de seção transversal de concreto, e onze modelos para o dimensionamento do reforço por encamisamento por polímero reforçado com fibras de carbono. Todos eles consideram o efeito do confinamento, proporcionado pela armadura transversal e pelo reforço com fibras, no ganho de resistência do pilar. Para a validação, foi montado um banco de dados contendo 135 pilares ensaiados em diversas pesquisas, ao qual foram aplicados os modelos em análise de modo a identificar aqueles que melhor expressam o comportamento do pilar reforçado. Ao final do trabalho, foi selecionado um modelo de confinamento por armadura transversal e onze combinações entre modelos de confinamento por fibras de carbono e armadura transversal que conduziram às melhores previsões de resistência dos pilares do banco de dados.

Palavras-chave: encamisamento, confinamento, fibras de carbono, aumento da seção transversal de concreto, modelos de dimensionamento.

Universidade Federal de Goiás, Goiânia, GO, Brasil. 


\section{Introduction}

Reinforced concrete structures are designed and built to withstand the stresses imposed throughout their life cycles. Occasionally, however, in the case of constructive defects or accidents, the constructions require retrofitting to improve their structural strength, increase their load capacity, expand their life cycles, or change the function of the building. This show the importance of developing adequate strengthening design models for concrete structures to guarantee their technical and economic viability.

Among the strengthening techniques for concrete structures, the use of concrete jackets and Carbon Fiber-Reinforced Polymer (CFRP) sheets is highlighted. In recent years, these techniques have been heavily used in columns, significantly increasing their load capacity.

Strengthening with a concrete jacket involves wrapping the column in a concrete layer. According to Takeuti [1], transverse and longitudinal steel reinforcements can be added to the concrete jacket, improving the column resistance for loads. In the case of strengthening by wrapping with CFRP, the column is surrounded by a composite material formed by carbon fibers filled with epoxy resin. Both techniques are effective, and it is necessary to carry out adequate studies of cost, availability of trained labor, and impact on the layout of the building to evaluate the most adequate solution.

The literature contains several design methods to evaluate the gain resistance of strengthened columns. However, since these models are mostly empirical, there is significant variability in the coefficients suggested by different authors. Moreover, the variation in the results of design models is due to the different considerations adopted by each author. Therefore, different amounts of reinforcement and CFRP sheet wrapping are obtained.

Thus, the main objective of this paper is to compare the common design models available in the literature. For this purpose, they were applied to a database with 135 columns tested in the laboratory and the models that achieved the highest efficiency were selected to represent the results of tests by means of statistical inference analysis. To evaluate strengthening with a concrete jacket, the design models proposed by Cusson and Paultre [2], Saatcioglu and Razvi [3], Frangou et al. [4], and the fib Model Code 2010 [5] were used. With regard to strengthening with CFRP sheet wrapping, $11 \mathrm{em}$ pirical models available in the literature were evaluated.

\section{Strengthening models for reinforced concrete columns}

The capacity of strengthened concrete columns subjected to uniaxial compression is calculated from the sum of resistances of concrete and steel reinforcement in the longitudinal direction. However, several researches showed the importance of the confinement by a concrete jacket for the capacity of the strengthened concrete columns.

According to Carrazedo [6], when the columns are loaded by longitudinal loads, they show lateral expansion because of the Poisson coefficient. However, when the columns are laterally restrained, triaxial compression stresses are induced, generating a gain in longitudinal resistance in the element. The confinement can be induced by CFRP sheet wrapping or transverse steel reinforcement.

This paper considers that in the columns wrapped by CFRP, the confinement is provided by both the transverse reinforcement and the CFRP sheet wrapping. For columns strengthened with concrete jackets, the confinement is provided by both transverse steel reinforcement in the concrete core and transverse steel reinforcement in the concrete jacket.

\subsection{Confinement due to transverse steel reinforcement}

The basic principle of strengthening with a concrete jacket is that the resistance of the strengthened column is due to the concrete and the longitudinal steel present in the core and in the concrete jacket. Takeuti [1] adds that the transverse steel reinforcement in

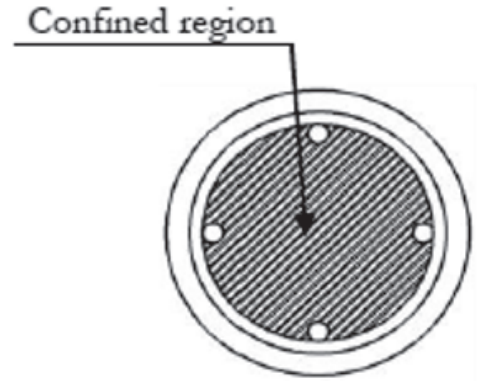

(a)

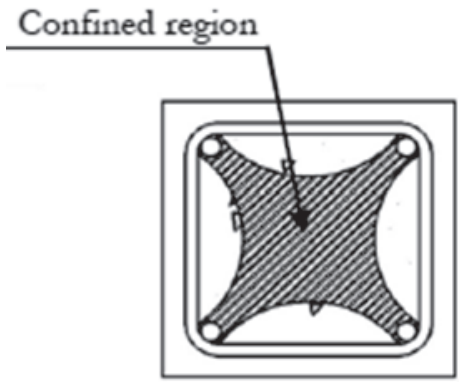

(b)

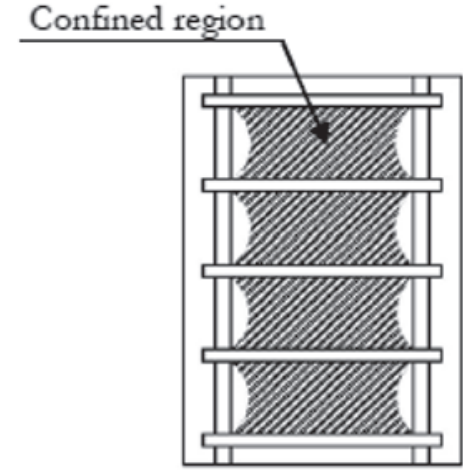

(c)

Figure 1

Column region that is confined by transverse reinforcement.. (a) Cross-section of circular confined columns; (b) Cross-section of rectangular confined columns; (c) Longitudinal section of confined columns (confinement between stirrups)

Source: Adapted from Cusson and Paultre [2] 
the core and in the concrete jacket ensures the confinement of the column, which consequently increases the strength of column.

The four design models analyzed considered that there is an internal area of the concrete core defined by the transverse reinforcement which is effectively confined, as shown in the hatched area in Figure 1. In circular columns, the confined area of the concrete core is the same as the edge of the transverse steel reinforcement. In columns with square or rectangular sections, there is an arching action of the confining stress due to transverse reinforcement, generating stress peaks in the corners where the transverse reinforcement meets the longitudinal reinforcements. The part of the section outside the confined area is considered as concrete cover and does not contribute to the strength of the column [2-4].

Takeuti [1] and Carrazedo [6] point out that cracking and spalling of concrete cover can happen with the application of axial loading on the column. Therefore, these authors recommend disregarding the concrete cover external to the transverse reinforcement.

\subsubsection{Cusson and Paultre model}

Based on experimental tests, Cusson and Paultre [2] defined a relationship between the strength gain of confined concrete and the effective confinement index (fle/fc) defined from the nominal lateral pressure of transverse reinforcement, which is given by Equation (1):

$f_{c c}=f_{c}\left[1+2.1\left(\frac{f_{l e}}{f_{c}}\right)^{0.7}\right]$

where:

$f_{c c}$ is the compressive strength of confined concrete,

$f_{c}$ is the compressive strength of the original concrete,

$f_{l e}$ is the nominal lateral pressure.

The authors adopt a confinement effectiveness coefficient, $K_{e}$, for a rectangular cross-section, which was evaluated by Mander, Priestley, and Park [7] as follows:

$f_{l e}=f_{l} K_{e}$

with:

$K_{e}=\frac{\left(1-\sum \frac{\left(w_{i}\right)^{2}}{6 c_{x} c_{y}}\right)\left(1-\frac{s^{\prime}}{2 c_{x}}\right)\left(1-\frac{s^{\prime}}{2 c_{y}}\right)}{\left(1-\rho_{l}\right)}$

where:

$f_{i}$ is the lateral pressure of transverse reinforcement,

$\mathrm{w}_{\mathrm{i}}$ is the clear spacing between adjacent longitudinal steel bars,

$c_{x}$ and $c_{y}$ are the dimensions of the column core perpendicular to the directions $x$ and $y$, respectively, measured between centers of the transverse reinforcements,

$s^{\prime}$ is the clear spacing of stirrups,

$\rho_{1}$ is the longitudinal reinforcement ratio in the core section.

Mander, Priestley, and Park [7] also establish the coefficient of confinement effectiveness $\mathrm{K}_{\mathrm{e}}$ for circular columns reinforced with conventional stirrups and with spirals according to Equations (3) and (4), respectively.

$K_{e}=\frac{\left(1-\frac{s^{\prime}}{2 d_{i}}\right)^{2}}{\left(1-\rho_{l}\right)}$

$K_{e}=\frac{\left(1-\frac{s^{\prime}}{2 d_{i}}\right)}{\left(1-\rho_{l}\right)}$ where:

$d_{i}$ is the diameter of circular stirrups or spiral between bar centers, The lateral confining stress on the concrete for rectangular columns is obtained from Equation (5):

$f_{l}=\frac{f_{y, t}}{s}\left(\frac{A_{s, t x}+A_{s, t y}}{c_{x}+c_{y}}\right)$

where:

$f_{y, t}$ is the yield strength of transverse reinforcement,

$\mathrm{A}_{\mathrm{s}, \mathrm{t} x}$ and $\mathrm{A}_{\mathrm{s}, \mathrm{t} y}$ are the total areas of the transverse reinforcement parallel to the $y$-axis and $x$-axis, respectively, corresponding to twice the cross-sectional area of the stirrups,

$\mathrm{s}$ is the center-to-center spacing between stirrups.

Cusson and Paultre [2] do not evaluate the lateral confining stress on the concrete for circular columns.

\subsubsection{Saatcioglu and Razvi's model}

The second model analyzed was proposed by Saatcioglu and Razvi [3] and was based on the same confinement principle as was used by Cusson and Paultre [2]. The difference lies in the empirical correlation between the variables.

The gain in concrete strength is evaluated as a function of the nominal lateral pressure by Equation (6).

$f_{c c}=f_{c}+6.7 f_{l e}^{0.83}$

The nominal lateral pressure is given by:

$f_{l e}=k_{2} f_{l}$

with:

$k_{2}=0.26 \sqrt{\left(\frac{b_{c}}{s}\right)\left(\frac{b_{c}}{w_{i}}\right)\left(\frac{1}{f_{l}}\right)} \leq 1.0$ for rectangular sections,

$k_{2}=1.0$ for circular sections.

and the lateral pressure of transverse reinforcement is given by Equation (8).

$f_{l}=\frac{\sum 2 A_{s, t} f_{y, t} \sin \theta}{s b_{c}}$

where:

$b_{c}$ is the distance between the centers of the longitudinal bars,

$A_{s, t}$ is the area of the transverse reinforcement,

$\theta$ is the angle between the transverse reinforcement and $b_{c}$ and is equal to $90^{\circ}$ for rectangular columns.

\subsubsection{Model of Frangou et al.}

Frangou et al. [4] proposed a model to evaluate the strength of confined concrete based on Eurocode 8 (CEN [8]) recommendations. This model differs from the others in that it considers the gain resistance of concrete as a function of its mechanical confinement rate $\omega_{w}$, as shown in Equations (9) and (10).

$f_{c c}=f_{c}\left(1.125+1.25 \alpha^{\prime} \omega_{w}\right)$ if $\alpha^{\prime} \omega_{w} \geq 0.1$

$f_{c c}=f_{c}\left(1+2.5 \alpha^{\prime} \omega_{w}\right)$ if $\alpha^{\prime} \omega_{w} \leq 0.1$

$\omega_{w}=\frac{A_{s, t} \pi d}{\frac{\pi d^{2}}{4} s} \frac{f_{y, t}}{f_{c}}=\frac{4 A_{s, t} f_{y, t}}{d s f_{c}}$ 
where:

$\alpha^{\prime}$ is a reduction factor, calculated from Equation (11),

$d$ is the diameter of the concrete section confined by the stirrups.

To evaluate the effective confinement on the column, Eurocode 8 (CEN [8]) uses a reduction factor $\alpha^{\prime}$ given by:

$\alpha^{\prime}=\alpha_{n} \alpha_{s}$

with:

$\alpha_{n}=\frac{c_{x} c_{y}-2\left(\frac{c_{x}{ }^{2}+c_{y}{ }^{2}}{6}\right)}{c_{x} c_{y}-A_{s, l}}$ for rectangular cross-sections,

$\alpha_{n}=\frac{1}{3}$ for square cross-sections,

$\alpha_{n}=1.0$ for circular cross-sections,

$\alpha_{s}=\frac{\left(c_{x}-\frac{s}{2}\right)\left(c_{y}-\frac{s}{2}\right)}{c_{x} c_{y}}$ for rectangular cross-sections,

$\alpha_{s}=\left(\frac{1-s}{2 d_{i}}\right)^{2}$ for circular cross-sections with conventional stirrups,

$\alpha_{s}=\left(\frac{1-s}{2 d_{i}}\right)$ for circular cross-sections with spirals.

where:

$A_{s, l}$ is the total area of longitudinal reinforcement of the column.

\subsection{4 fib Model Code}

The fib Model Code 2010 [5] determines the gain resistance of the transverse reinforced confined column from Equation (12):

$f_{c c}=f_{c}\left[1+3.5\left(\frac{f_{l e}}{f_{c}}\right)^{\frac{3}{4}}\right]$

The nominal lateral confinement pressure for circular and rectangular cross-sections is given by Equations (13) and (14), respectively.

$f_{l e}=\omega_{c} f_{c}\left(1-\frac{s}{d_{i}}\right)$ for a section confined by spirals,

$f_{l e}=\omega_{c} f_{c}\left(1-\frac{s}{d_{i}}\right)^{2}$ for a section confined by conventional stirrups with:

$\omega_{c}=\frac{2 A_{s, t} f_{y, t}}{s d_{i} f_{c}}$

$f_{l e}=\omega_{c} f_{c}\left(1-\frac{s}{c_{x}}\right)\left(1-\frac{s}{c_{y}}\right)\left(1-\frac{\sum b_{c}^{2}}{6 c_{x} c_{y}}\right)$

with:

$\omega_{c}=\min \left(\frac{A_{s, t x} f_{y, t}}{s c_{x} f_{c}}, \frac{A_{s, t y} f_{y, t}}{s c_{y} f_{c}}\right)$

\subsection{CFRP confinement models}

The design models for confinement with CFRP sheet wrapping are based on the same confinement principles as are used for confinement with steel reinforcement. The load capacity of the column is

\section{Table 1}

Expressions for evaluating the compressive strength of confined concrete with FRP

\begin{tabular}{|c|c|c|}
\hline Reference & Confinement type & $f_{c c}$ \\
\hline Samaan et al. [10] & GFRP & $f_{c}+6.0 f_{l, f}^{0.7}$ \\
\hline Miyauchi et al. [11] & CFRP & $f_{c}\left[1+3.5 \frac{f_{l, f}}{f_{c}}\right]$ \\
\hline Kono et al. [12] & CFRP & $f_{c}\left(1+0.0572 f_{l, f}\right)$ \\
\hline Toutanji [13] & CFRP GFRP & \begin{tabular}{l|l}
$f_{c}$ & $1+3.5\left(\frac{l, f}{f_{c}}\right)$
\end{tabular} \\
\hline Saafi et al. [14] & CFRP GFRP & \begin{tabular}{l|l}
$f_{c}$ & $1+2.2\left(\frac{\rho, f}{f_{c}}\right)$
\end{tabular} \\
\hline Spoelstra and Monti [15] & CFRP GFRP & \begin{tabular}{l|l|l}
$f_{c}$ & $0.2+3$
\end{tabular} \\
\hline Fardis and Khalili [16] & GFRP & $\left.2.05 \frac{f_{l, f}}{f_{c}}\right)$ \\
\hline Karbhari and Eckel [17] & CFRP GFRP AFRP & \begin{tabular}{l|l}
$f_{c}$ & $1+2.1\left(\frac{J_{l, f}}{f_{c}}\right)$
\end{tabular} \\
\hline Mirmiran and Shahawy [18] & GFRP & $f_{c}+4.269 f_{l, f}^{0.587}$ \\
\hline Shehata, Carneiro, and Shehata [19] & CFRP & $f_{c}\left(1+\beta \frac{f_{l, f}}{f_{c}}\right) *$ \\
\hline
\end{tabular}

\footnotetext{
${ }^{*} \beta$ is equal to 2.0 for a circular section, 0.85 for a square section, and 0.7 for a rectangular section
} 
guaranteed by the strength of the confined concrete and the longitudinal steel of the core.

There are several researches in the literature about the confinement of concrete by CFRP sheet wrapping. Table 1 lists some of empirical models that were analyzed in this paper, which depend of the strength of confined concrete. On the other hand, the strength of confined concrete as a function of the strength of the existing concrete and the lateral pressure from the CFRP sheet wrapping and can be calculated from Equation (15).

$f_{l, f}=\frac{2 n t_{f} f_{f} k_{a}}{D}$ for circular columns

$f_{l, f}=\frac{f_{l, f(b)}+f_{l, f(h)}}{2}=\frac{n t_{f} f_{f} k_{a}(b+h)}{b+h}$ for rectangular columns

where:

$f_{l, f}$ is the lateral pressure from the CFRP sheet wrapping,

$\mathrm{n}$ is the number of CFRP sheets,

$t_{f}$ is the thickness of the CFRP sheet,

$\mathrm{f}_{\mathrm{f}}$ is the tensile strength of the CFRP sheet,

$k_{a}$ is the confinement effectiveness coefficient. For circular columns, it is considered to be full confinement, that is, $\mathrm{k}_{\mathrm{a}}=1.0$,

$\mathrm{D}$ is the diameter of the circular columns,

$\mathrm{b}$ and $\mathrm{h}$ are the width and height of the cross-section of the rectangular columns, respectively.

Note from Equation (15) that lateral pressure in the column depends on the tensile strength of the CFRP sheet, which is directly influenced by several properties of the FRP (Fiber Reinforced Polymers), such as the modulus of elasticity and deformation of fibers, thickness, and number of FRP layers. Several researches have carried out tests to propose expressions that already include these basic parameters for the main types of commercialized FRP systems, that is, CFRP, GFRP (Glass Fiber Reinforced Polymers), and AFRP (Aramid Fiber Reinforced Polymers). Thus, the expressions obtained from tests with other types of fibers can also be efficiently applied in the calculation of the confinement with CFRP sheets and are included in Table 1.

The expressions in Table 1 were obtained from tests with columns strengthened only with FRP sheets, without transverse or longitudinal reinforcements. Thus, they depend only on the lateral pressure due to the FRP jacket. For columns strengthened with CFRP sheets and transverse reinforcement, the equations shown in Table 1 can be associated with the confinement models with transverse reinforcement described in Subsection 2.1, as shown in Figure 2 and discussed in the next section.

\subsection{Models for evaluation of confinement with transverse reinforcement and FRP sheet wrapping}

The confinement of the concrete core of columns with transverse reinforcement is well-known. However, there are still doubts about the interaction between FRP sheet wrapping and transverse reinforcement used to confine the concrete core of columns. Carrazedo [6] considers that the interaction of FRP sheets and transverse reinforcement in the confinement of concrete can be evaluated by adding the strength gain obtained for each strengthening system individually. That is, initially the transverse reinforcement confines the concrete of the column and offers a resistance gain of $f_{c c, e}$. Subsequently, the FRP sheet wrapping provides a resistance gain of $f_{c c, f}$ to the unconfined concrete core. The total resistance of the confined concrete is given by Equation (16):

$f_{c c}=f_{c}+f_{c c, f}+f_{c c, e}$

Another proposal that considered this interaction was presented by Machado [9] and was based on the recommendations of $\mathrm{ACl} 440$. According to this author, the strength of the confined concrete of the reinforced column can be evaluated from an empirical equation that considers the lateral pressure generated by the strengthening system and the strength of the original concrete, as shown in Equation (17).

$f_{c c}=f_{c}\left[2.25 \sqrt{1+\frac{7.9 f_{l}}{f_{c}}}-\frac{2 f_{l}}{f_{c}}-1.25\right]$

This formulation is based on the hypothesis that the total lateral pressures on the column are due to the sum of the lateral

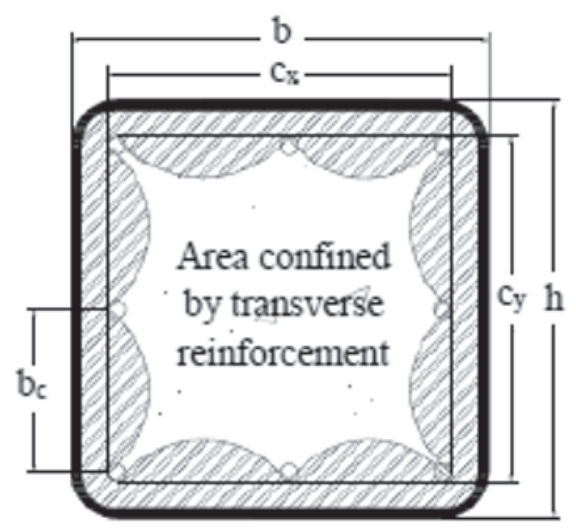

(b)

Figure 2

Effectively confined area of column. (a) Confinement with CFRP; (b) Confinement with transverse reinforcement. Source: Modified from Machado [9] 

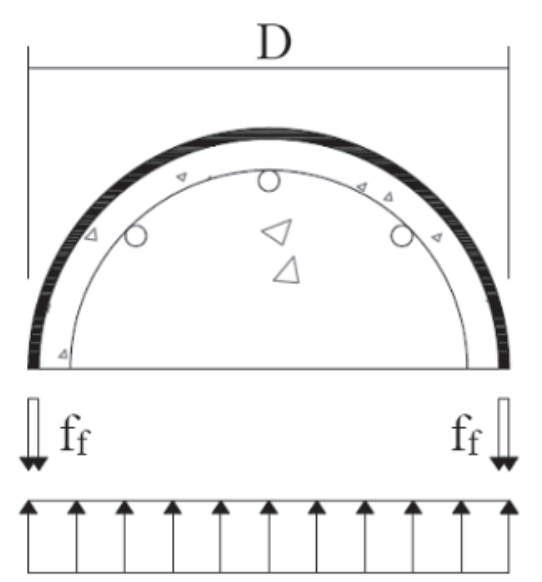

$f_{1, f}$
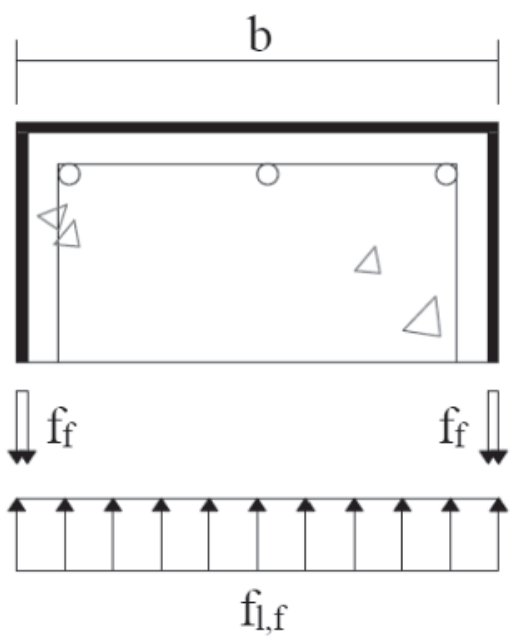

$f_{l, f}$

(a)

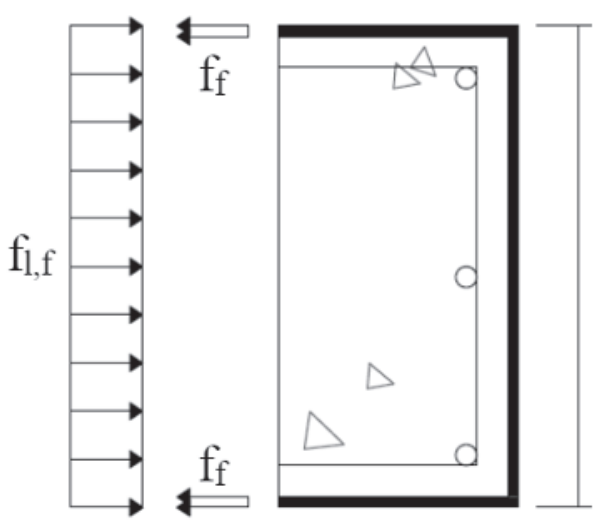

(b)

Figure 3

Lateral pressure due to CFRP sheet wrapping. (a) Circular columns; (b) Rectangular columns

Source: Modified from Machado [9]

pressures of the different strengthening systems, that is, FRP sheet wrapping and transverse reinforcement, as shown in Figure 3 . Then, the total lateral pressure $f_{i}$ is calculated from Equation (18), in a different procedure from Equation (16), which evaluates the strength of confined concrete independently from each strengthening system.

$f_{l}=f_{l, e}+f_{l, f}$

where:

$\mathrm{f}_{\mathrm{l}, \mathrm{e}}$ is the lateral pressure from the transverse reinforcement,

$\mathrm{f}_{\mathrm{l}, \mathrm{f}}$ is the lateral pressure from the CFRP sheet wrapping.

The lateral pressures from the CFRP sheet wrapping and the transverse reinforcement are evaluated by Equations (15) and (19), respectively. In circular sections, the pressure distribution is uniform, while the lateral pressure is proportional to the cross-sectional dimensions of the rectangular column.

$f_{l, e}=\frac{2 A_{s, t} f_{y, t} k_{b}}{s d_{i}}$ for circular columns

$f_{l, e}=\frac{A_{s, t} f_{y, t} k_{b}(b+h)}{s b h}$ for rectangular columns

where:

$k_{b}$ is the coefficient of confinement effectiveness,

Full confinement of circular columns section is considered, thus $k_{b}=1.0$. For rectangular columns, Machado [9] uses Equation (20) to evaluate the confinement effectiveness coefficients $\mathrm{k}_{\mathrm{a}}$ and $\mathrm{k}_{\mathrm{b}}$ required in Equations (15) and (19).

$k_{a}=k_{b}=1-\frac{\left(b-2 r^{\prime}\right)^{2}+\left(h-2 r^{\prime}\right)^{2}}{3 b h\left(1-\rho_{t}\right)}$

$r^{\prime}=\frac{h}{b} \leq 1.5$

$\rho_{t}=\frac{A_{s, t}}{A_{g}}$ where:

$\rho_{\mathrm{t}}$ is the ratio between transverse reinforcement and the column section area,

$A_{g}$ is the cross-sectional area of the column.

\section{Analysis of design models for strengthening of reinforced concrete columns}

The analysis of the design models described was done using a database of 135 columns that have been tested and are available in the literature. The design models shown in Section 2 were applied to this database and the results were compared to the resistance gain observed in the experimental tests. The analysis was subdivided into two parts, that is, strengthening with a concrete jacket and strengthening with CFRP sheet wrapping. Later, strengthening with both transverse reinforcement and CFRP sheet wrapping was also analyzed.

\subsection{Strengthening with concrete jacket}

A set of four columns tested by Takeuti [1] was used to evaluate the efficiency of the design models for predicting the resistance of reinforced columns strengthened with concrete jackets. All columns had an original square cross-section of $15 \times 15 \mathrm{~cm}$ and were placed in concrete jackets of either 3 or $4 \mathrm{~cm}$ thick. Longitudinal and transverse reinforcements were added to the core and concrete jacket, as shown in Figure 4. The database for this strengthening system is small since there are few studies in the literature on reinforcement by wrapping with a concrete jacket.

The four design models for evaluating the confinement with transverse reinforcement were applied to this database. The strength of the column with the concrete jacket was determined by adding the strength of longitudinal reinforcements to the strength of concrete 


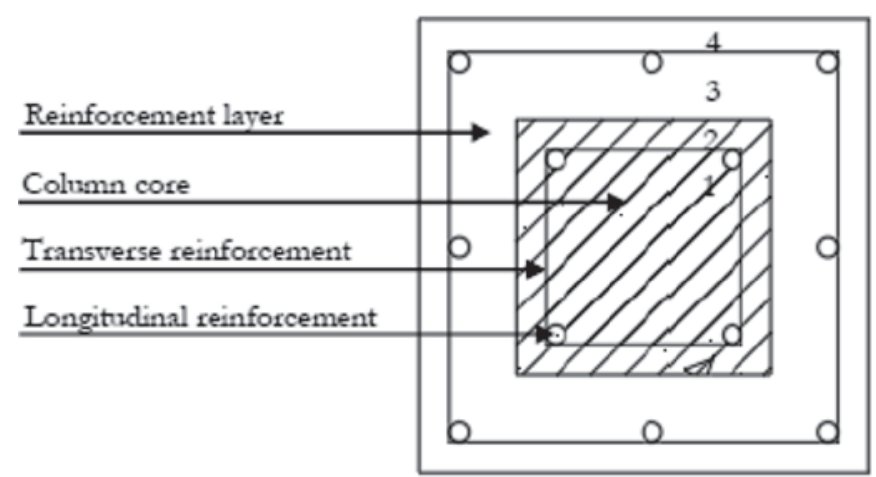

\section{Figure 4}

Cross-sectional area of column strengthened with concrete jacket

shown in Regions 1, 2, and 3 in Figure 4. Region 4, which is external to the transverse reinforcement, was disregarded. Only the cross-section of the original column was considered to be confined by the transverse reinforcement. Region 1 was confined due to transverse reinforcement placed on the concrete core and on the concrete jacket, while Region 2 was confined only by the transverse reinforcement placed on the concrete jacket.

Table 2 shows the comparison between the strength predicted by each model and the strength obtained experimentally for each column. It is observed that, on average, all models predicted values within the acceptable range for safety, that is, values for the ratio of maximum theoretical strength to maximum experimental strength $\left(F_{u \text { theor }} / F_{u, e x p}\right)$ smaller than one. In addition, all models showed similar effectiveness, although different expressions were used, with an average difference of $10 \%$ from values obtained in the tests.

\subsection{Strengthening with CFRP sheet wrapping}

Several tests of strengthening of reinforced concrete columns with CFRP have been presented in the literature. Three situations shown in Figure 5 were analyzed. Initially, the confinement models with CFRP sheet wrapping (Table 1) were applied to columns that were wrapped with FRP and without transverse reinforcement. Then, the confinement models with transverse reinforcement shown in Subsection 2.1 were applied to circular columns with transverse reinforcement and without the presence of the CFRP sheet. The results
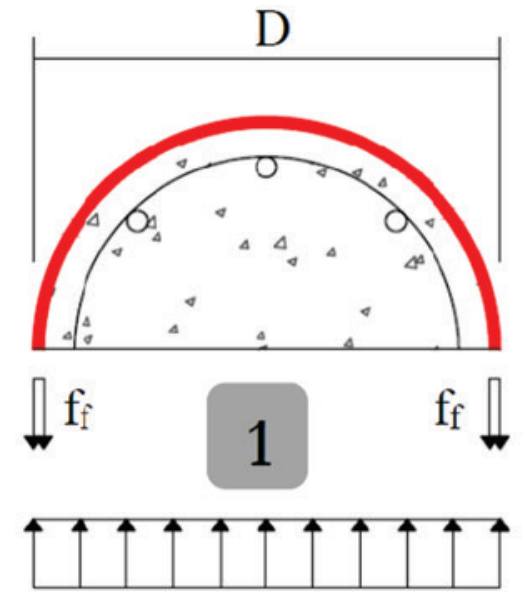

$f_{1, f}$
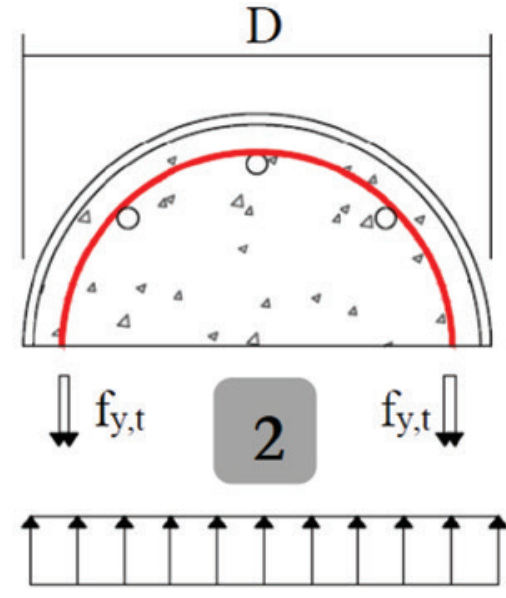

$\mathrm{f}_{\mathrm{l}, \mathrm{e}}$
$\mathrm{D}$
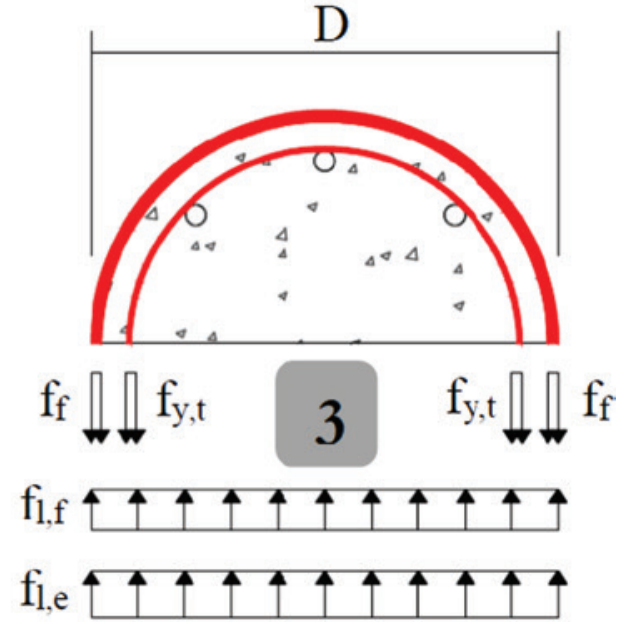

\section{Figure 5}

Confinement generated due to the FRP and the transverse reinforcement. Step 1: Confinement with FRP; Step 2: Confinement with transverse reinforcement; Step 3: Confinement with FRP and transverse reinforcement

\section{Table 2}

Comparison between the design models for strengthening with concrete jacket $\Delta=\mathrm{F}_{\mathrm{u} \text {,theor }} / \mathrm{F}_{\mathrm{u}, \mathrm{exp}}$

\begin{tabular}{|c|c|c|c|c|c|c|c|c|c|}
\hline \multirow[b]{2}{*}{ Model } & \multirow[b]{2}{*}{$\begin{array}{l}F_{u, e x p} \\
(K N)\end{array}$} & \multicolumn{2}{|c|}{ Cusson and Paultre [2] } & \multicolumn{2}{|c|}{ Saatcioglu and Razvi [3] } & \multicolumn{2}{|c|}{ Frangou et al. [4] } & \multicolumn{2}{|c|}{ fib Model Code 2010 [5] } \\
\hline & & $\begin{array}{c}F_{\mathrm{u}, \text { theor }} \\
(\mathrm{kN})\end{array}$ & $\Delta$ & $\begin{array}{l}F_{\text {utheor }} \\
(\mathrm{kN})\end{array}$ & $\Delta$ & $\begin{array}{l}F_{\text {utheor }} \\
(\mathrm{KN})\end{array}$ & $\Delta$ & $\begin{array}{l}F_{\text {utheor }} \\
(\mathrm{kN})\end{array}$ & 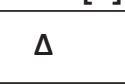 \\
\hline SICIS & 1540 & 1356 & 0.88 & 1394 & 0.91 & 1324 & 0.86 & 1340 & 0.87 \\
\hline $\mathrm{S1C2S}$ & 1749 & 1276 & 0.73 & 1295 & 0.74 & 1320 & 0.75 & 1259 & 0.72 \\
\hline $\mathrm{S} 2 \mathrm{C} 1 \mathrm{~S}$ & 1850 & 1841 & 0.99 & 1876 & 1.01 & 1813 & 0.98 & 1823 & 0.99 \\
\hline $\mathrm{S} 1 \mathrm{C} 2 \mathrm{~S}$ & 1840 & 1749 & 0.95 & 1765 & 0.96 & 1780 & 0.97 & 1727 & 0.94 \\
\hline Mean & - & - & 0.89 & - & 0.90 & - & 0.89 & - & 0.88 \\
\hline $\mathrm{CV}^{*}$ & - & - & 0.13 & - & 0.13 & - & 0.12 & - & 0.13 \\
\hline
\end{tabular}

\footnotetext{
${ }^{*} \mathrm{CV}=$ coefficient of variation
} 
Table 3

Database of reinforced circular columns strengthened with FRP

\begin{tabular}{|c|c|c|c|c|c|c|c|c|c|c|c|c|c|}
\hline \multirow{2}{*}{ Reference } & \multirow{2}{*}{ Column } & \multicolumn{3}{|c|}{ Dimensions } & \multicolumn{6}{|c|}{ FRP } & \multicolumn{3}{|c|}{$\begin{array}{l}\text { Experimental } \\
\text { conditions }\end{array}$} \\
\hline & & $\begin{array}{c}\text { D } \\
(\mathrm{mm})\end{array}$ & $\underset{(\mathrm{mm})}{\mathbf{H}}$ & $\lambda$ & $\begin{array}{l}\text { Fiber } \\
\text { type }\end{array}$ & $\left(\begin{array}{c}t_{f} \\
(\mathrm{~mm})\end{array}\right.$ & $\begin{array}{c}\xi_{\mathrm{f}} \\
(\% \circ)\end{array}$ & $\begin{array}{c}E_{f} \\
(\mathrm{MPa})\end{array}$ & $\begin{array}{c}f_{f} \\
(M P a)\end{array}$ & $\mathrm{n}$ & $\begin{array}{c}f_{c} \\
(M P a)\end{array}$ & $\begin{array}{c}f_{1} \\
(\mathrm{MPa})\end{array}$ & $\begin{array}{l}f_{c c, e x p} \\
(\mathrm{MPa})\end{array}$ \\
\hline \multirow{2}{*}{ Carrazedo [6] } & $\mathrm{Cl}$ & 190 & 570 & 12 & CFRP & 0.130 & 11.92 & 218950 & 2610 & 1 & 26.16 & 3.57 & 38.81 \\
\hline & $\mathrm{C} 2$ & 190 & 570 & 12 & CFRP & 0.130 & 10.89 & 218950 & 2384 & 2 & 26.16 & 6.53 & 53.08 \\
\hline \multirow{4}{*}{$\begin{array}{l}\text { Shehata, } \\
\text { Carneiro, and } \\
\text { Shehata [19] }\end{array}$} & C1-25a & 150 & 300 & 8 & CFRP & 0.165 & 15.00 & 235000 & 3525 & 1 & 25.60 & 7.76 & 43.90 \\
\hline & $c 2-30 a$ & 150 & 300 & 8 & CFRP & 0.165 & 15.00 & 235000 & 3525 & 1 & 29.80 & 7.76 & 57.00 \\
\hline & C1-25b & 150 & 300 & 8 & CFRP & 0.165 & 15.00 & 235000 & 3525 & 2 & 25.60 & 15.51 & 59.60 \\
\hline & c2-30b & 150 & 300 & 8 & CFRP & 0.165 & 15.00 & 235000 & 3525 & 2 & 29.80 & 15.51 & 72.10 \\
\hline \multirow{22}{*}{$\begin{array}{l}\text { Samaan et al. } \\
{[10]}\end{array}$} & DA11 & 153 & 305 & 8 & GFRP & 0.240 & - & - & 579.2 & 6 & 30.86 & 10.94 & 53.66 \\
\hline & DA13 & 153 & 305 & 8 & GFRP & 0.240 & - & - & 579.2 & 6 & 30.86 & 10.94 & 56.50 \\
\hline & DB1 1 & 153 & 305 & 8 & GFRP & 0.240 & - & - & 579.2 & 6 & 29.64 & 10.94 & 67.12 \\
\hline & $\mathrm{DB} 12$ & 153 & 305 & 8 & GFRP & 0.240 & - & - & 579.2 & 6 & 29.64 & 10.94 & 55.29 \\
\hline & $\mathrm{DB} 13$ & 153 & 305 & 8 & GFRP & 0.240 & - & - & 579.2 & 6 & 29.64 & 10.94 & 60.23 \\
\hline & $\mathrm{DC} 11$ & 153 & 305 & 8 & GFRP & 0.240 & - & - & 579.2 & 6 & 31.97 & 10.94 & 59.06 \\
\hline & $\mathrm{DC} 12$ & 153 & 305 & 8 & GFRP & 0.240 & - & - & 579.2 & 6 & 31.97 & 10.94 & 60.79 \\
\hline & DA21 & 153 & 305 & 8 & GFRP & 0.220 & - & - & 579.2 & 10 & 30.86 & 16.71 & 72.92 \\
\hline & DA22 & 153 & 305 & 8 & GFRP & 0.220 & - & - & 579.2 & 10 & 30.86 & 16.71 & 65.67 \\
\hline & DA23 & 153 & 305 & 8 & GFRP & 0.220 & - & - & 579.2 & 10 & 30.86 & 16.71 & 77.99 \\
\hline & DB21 & 153 & 305 & 8 & GFRP & 0.220 & - & - & 579.2 & 10 & 29.64 & 16.71 & 74.56 \\
\hline & DB22 & 153 & 305 & 8 & GFRP & 0.220 & - & - & 579.2 & 10 & 29.64 & 16.71 & 93.02 \\
\hline & DB23 & 153 & 305 & 8 & GFRP & 0.220 & - & - & 579.2 & 10 & 29.64 & 16.71 & 71.77 \\
\hline & DC21 & 153 & 305 & 8 & GFRP & 0.220 & - & - & 579.2 & 10 & 31.97 & 16.71 & 77.35 \\
\hline & DC22 & 153 & 305 & 8 & GFRP & 0.220 & - & - & 579.2 & 10 & 31.97 & 16.71 & 77.08 \\
\hline & DA31 & 153 & 305 & 8 & GFRP & 0.212 & - & - & 579.2 & 14 & 30.86 & 22.56 & 85.72 \\
\hline & DA33 & 153 & 305 & 8 & GFRP & 0.212 & - & - & 579.2 & 14 & 30.86 & 22.56 & 86.76 \\
\hline & DB31 & 153 & 305 & 8 & GFRP & 0.212 & - & - & 579.2 & 14 & 29.64 & 22.56 & 86.22 \\
\hline & DB32 & 153 & 305 & 8 & GFRP & 0.212 & - & - & 579.2 & 14 & 29.64 & 22.56 & 114.66 \\
\hline & DB33 & 153 & 305 & 8 & GFRP & 0.212 & - & - & 579.2 & 14 & 29.64 & 22.56 & 87.44 \\
\hline & DC31 & 153 & 305 & 8 & GFRP & 0.212 & - & - & 579.2 & 14 & 31.97 & 22.56 & 86.11 \\
\hline & DC32 & 153 & 305 & 8 & GFRP & 0.212 & - & - & 579.2 & 14 & 31.97 & 22.56 & 83.99 \\
\hline \multirow{6}{*}{$\begin{array}{l}\text { Eid, Roy, and } \\
\text { Paultre [20] }\end{array}$} & N1 & 152 & 300 & 8 & CFRP & 0.381 & 13.40 & 78000 & 1045 & 1 & 32.10 & 5.24 & 39.71 \\
\hline & N2 & 152 & 300 & 8 & CFRP & 0.381 & 13.40 & 78000 & 1045 & 2 & 32.10 & 10.48 & 57.58 \\
\hline & N3 & 152 & 300 & 8 & CFRP & 0.381 & 13.40 & 78000 & 1045 & 3 & 33.60 & 15.72 & 74.24 \\
\hline & M1 & 152 & 300 & 8 & CFRP & 0.381 & 13.40 & 78000 & 1045 & 1 & 48.00 & 5.24 & 59.80 \\
\hline & M2 & 152 & 300 & 8 & CFRP & 0.381 & 13.40 & 78000 & 1045 & 2 & 48.00 & 10.48 & 80.04 \\
\hline & M3 & 152 & 300 & 8 & CFRP & 0.381 & 13.40 & 78000 & 1045 & 3 & 48.00 & 15.72 & 99.84 \\
\hline \multirow{4}{*}{$\begin{array}{c}\text { Wang et al. } \\
\text { [21] }\end{array}$} & CIHOLIM & 305 & 915 & 12 & CFRP & 0.167 & 17.79 & 244000 & 4340 & 1 & 24.50 & 4.75 & 35.00 \\
\hline & C1HOL2M & 305 & 915 & 12 & CFRP & 0.167 & 17.79 & 244000 & 4340 & 2 & 24.50 & 9.51 & 55.30 \\
\hline & C2HOL1M & 204 & 612 & 12 & CFRP & 0.167 & 17.79 & 244000 & 4340 & 1 & 24.50 & 7.11 & 46.10 \\
\hline & C2HOL2M & 204 & 612 & 12 & CFRP & 0.167 & 17.79 & 244000 & 4340 & 2 & 24.50 & 14.21 & 65.20 \\
\hline \multirow{5}{*}{ Lee et al. [22] } & SOF1 & 150 & 300 & 8 & CFRP & 0.110 & 18.04 & 250000 & 4510 & 1 & 36.20 & 6.61 & 41.70 \\
\hline & SOF2 & 150 & 300 & 8 & CFRP & 0.110 & 18.04 & 250000 & 4510 & 2 & 36.20 & 13.23 & 57.80 \\
\hline & SOF3 & 150 & 300 & 8 & CFRP & 0.110 & 18.04 & 250000 & 4510 & 3 & 36.20 & 19.84 & 69.10 \\
\hline & SOF4 & 150 & 300 & 8 & CFRP & 0.110 & 18.04 & 250000 & 4510 & 4 & 36.20 & 26.46 & 85.40 \\
\hline & SOF5 & 150 & 300 & 8 & CFRP & 0.110 & 18.04 & 250000 & 4510 & 5 & 36.20 & 33.07 & 104.30 \\
\hline
\end{tabular}

Table 4

Comparison between theoretical and experimental results for columns strengthened with FRP

\begin{tabular}{|c|c|c|c|c|c|c|c|c|c|c|}
\hline \multirow[b]{2}{*}{ Reference } & \multicolumn{10}{|c|}{$\mathbf{f}_{\mathrm{cc}, \text { theor }} / \mathbf{f}_{\mathrm{cc}, \exp }$} \\
\hline & $\begin{array}{c}\text { Fardis } \\
\text { and } \\
\text { Khalili } \\
{[16]}\end{array}$ & $\begin{array}{c}\text { Karbhari } \\
\text { and Eckel } \\
{[17]}\end{array}$ & $\begin{array}{c}\text { Mirmiran } \\
\text { and } \\
\text { Shahawy } \\
{[18]}\end{array}$ & $\begin{array}{l}\text { Miyauchi } \\
\text { et al. [11] }\end{array}$ & $\begin{array}{l}\text { Samaan } \\
\text { et al. [10] }\end{array}$ & $\begin{array}{l}\text { Saafi et } \\
\text { al. [14] }\end{array}$ & $\begin{array}{c}\text { Toutanji } \\
\text { [13] }\end{array}$ & $\begin{array}{c}\text { Spoelstra } \\
\text { and Monti } \\
{[15]}\end{array}$ & $\begin{array}{l}\text { Kono et } \\
\text { al. [12] }\end{array}$ & $\begin{array}{c}\text { Shehata, } \\
\text { Carneiro, } \\
\text { and } \\
\text { Shehata } \\
{[19]}\end{array}$ \\
\hline Mean & 0.90 & 0.96 & 0.78 & 1.20 & 1.04 & 0.99 & 1.29 & 1.01 & 0.85 & 0.89 \\
\hline CV & 0.12 & 0.12 & 0.17 & 0.12 & 0.12 & 0.12 & 0.11 & 0.11 & 0.15 & 0.12 \\
\hline
\end{tabular}


Table 5

Results of student's t-test for columns strengthened with FRP. t-critical $=2.01808$

\begin{tabular}{cc}
\hline Reference & T \\
\hline Fardis and Khalili [16] & 5.57413 \\
Karbahari and Eckel [17] & 2.83641 \\
Mirmiran and Shahawy [18] & 8.84600 \\
Miyauchi et al. [11] & -7.66059 \\
Samaan et al. [10] & -0.83592 \\
Saafi et al. [14] & 1.08314 \\
Toutanji [13] & -11.17020 \\
Spoelstra and Monti [15] & -0.10101 \\
Kono et al. [12] & 6.71226 \\
Shehata, Carneiro and Shehata [19] & 6.08063 \\
\hline
\end{tabular}

were analyzed to verify the effectiveness of each model separately to predict the resistance of strengthened concrete columns. Finally, the interaction between the two strengthening systems was investigated in columns with transverse reinforcement and wrapped with FRP. For this purpose, the association between the calculation models presented in Sections 2.1 and 2.2 was investigated.

\subsubsection{Columns strengthened only with CFRP}

The first analysis considered a database with 43 columns strengthened only with FRP (Table 3). The database contained twenty-two columns tested by Samaan et al. [10], two tested by Carrazedo [6], four tested by Shehata, Carneiro, and Shehata [19], six tested by Eid, Roy, and Paultre [20], four tested by Wang et al. [21], and five tested by Lee et al. [22]. They were all short columns, with a circular cross-section, a diameter varying between 150 and $305 \mathrm{~mm}$, and concrete compressive strength varying from 24.5 to $48 \mathrm{MPa}$. Twenty-one columns were strengthened with glass fibers and twenty-two with CFRP. Table 3 compares the strength of confined concrete obtained from confinement models with FRP $\left(f_{c c, \text { theor }}\right)$ with the values obtained from the experiments $\left(f_{c c, e x p}\right)$. These columns

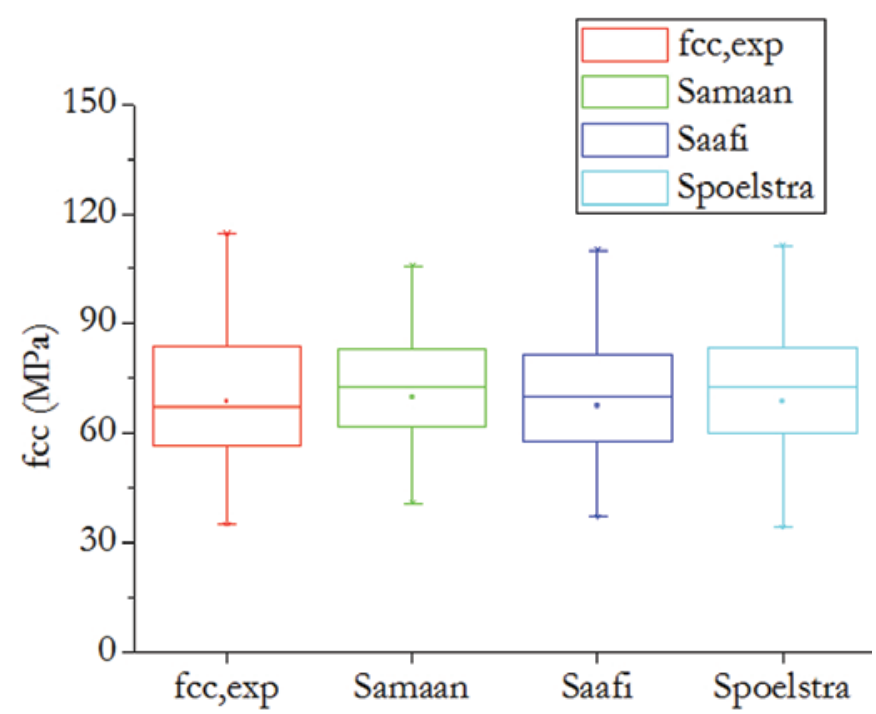

Figure 6

Variability of confinement models with FRP when compared to experimental values

did not have longitudinal reinforcement, so their strength was due only to the strength of confined concrete.

A general view shows that the models of Fardis and Khalili [16], Karbhari and Eckel [17], Samaan et al. [10], Saafi et al. [14], and Spoelstra and Monti [15] achieved the best predictions, with an error of less than $10 \%$ compared to the experimental values. The coefficient of variation for all models also remained acceptable at around $12 \%$.

Due to the bigger database, a bilateral paired Student's t-test was performed. The t-test is used to determine whether two sets of data are significantly different from each other [25]. The population variance was unknown and a significance level $(\alpha)$ of $10 \%$ was used for analysis. Table 5 shows the results obtained for the test variable ( $t$ ) and the critical value of this variable ( $\mathrm{t}$ critical). From this

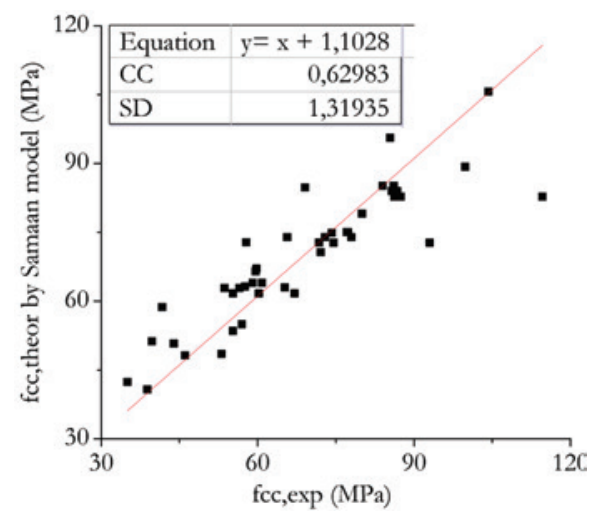

(a)

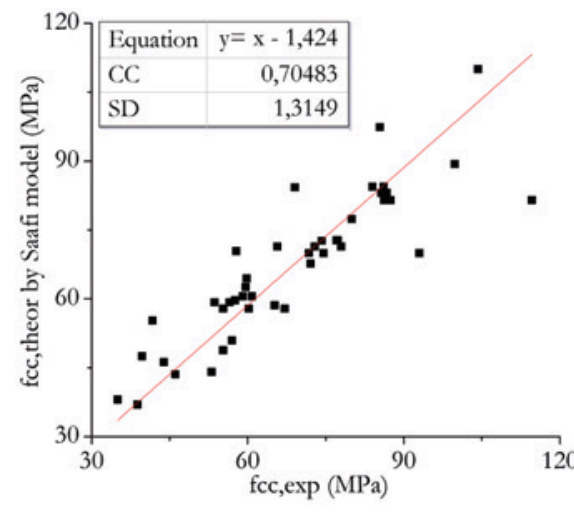

(b)

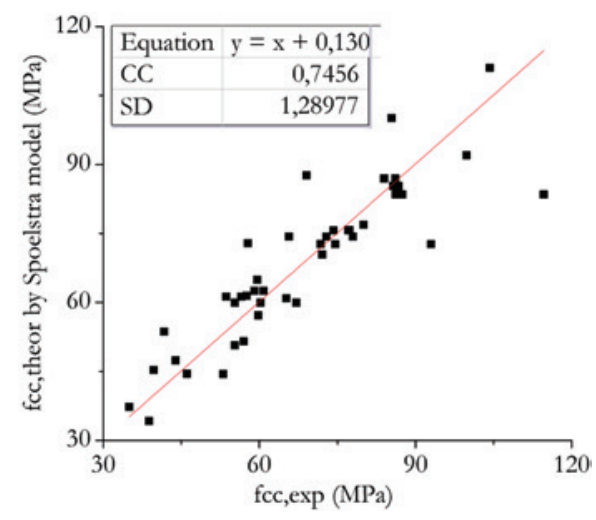

(c)

\section{Figure 7}

Comparison of theoretical and experimental results of compressive strength of confined concrete $\left(f_{c c}\right)$ due to confinement with FRP. (a) Samaan's model; (b) Saafi's model; (c) Spoelstra's model. CC: Correlation coefficient; SD: Standard deviation 
Table 6

Database of reinforced columns confined with transverse reinforcement

\begin{tabular}{|c|c|c|c|c|c|c|c|c|c|c|c|c|c|c|}
\hline \multirow{2}{*}{ Reference } & \multirow{2}{*}{ Model } & \multicolumn{3}{|c|}{ Dimensions } & \multicolumn{3}{|c|}{$\begin{array}{l}\text { Longitudinal } \\
\text { reinforcement }\end{array}$} & \multicolumn{5}{|c|}{ Transverse reinforcement } & \multicolumn{2}{|c|}{$\begin{array}{c}\text { Experimental } \\
\text { conditions }\end{array}$} \\
\hline & & $\underset{(\mathrm{mm})}{\mathbf{D}}$ & $\underset{(\mathrm{mm})}{\mathbf{H}}$ & $\lambda$ & $\begin{array}{c}\phi \mathbf{l} \\
(\mathrm{cm})\end{array}$ & $n^{\circ}$ & $\begin{array}{c}f_{\mathrm{y} .1} \\
(\mathrm{MPa})\end{array}$ & Type & $\begin{array}{c}\phi \dagger \\
(\mathrm{cm})\end{array}$ & $\begin{array}{c}\mathrm{s} \\
(\mathrm{mm})\end{array}$ & $\begin{array}{c}f_{y, t} \\
\left(M P{ }^{\prime} a\right)\end{array}$ & $\begin{array}{c}c \\
(\mathrm{~cm})\end{array}$ & $\begin{array}{c}f_{c} \\
(\mathrm{MPa})\end{array}$ & $\begin{array}{l}f_{c c, e x p} \\
(\mathrm{MPa})\end{array}$ \\
\hline \multirow{2}{*}{$\begin{array}{c}\text { Carrazedo } \\
\text { [6] }\end{array}$} & Cos50 & 190 & 570 & 12 & 0.8 & 6 & 554.8 & Spirals & 0.50 & 50 & 756 & 1.5 & 26.16 & 39.44 \\
\hline & $\cos 25$ & 190 & 570 & 12 & 0.8 & 6 & 554.8 & Spirals & 0.50 & 25 & 756 & 1.5 & 28.86 & 60.52 \\
\hline \multirow{4}{*}{$\begin{array}{c}\text { Eid, Roy, } \\
\text { and } \\
\text { Paultre } \\
{[20]}\end{array}$} & C4NPOC & 303 & 1200 & 16 & 1.6 & 6 & 423 & Spirals & 1.13 & 100 & 456 & 2.5 & 31.70 & 2930 \\
\hline & C4N1POC & 303 & 1200 & 16 & 1.6 & 6 & 423 & Spirals & 1.13 & 100 & 456 & 2.5 & 36.00 & 3235 \\
\hline & C2NPOC & 303 & 1200 & 16 & 1.6 & 6 & 423 & Spirals & 1.13 & 65 & 456 & 2.5 & 31.70 & 3000 \\
\hline & C2N1POC & 303 & 1200 & 16 & 1.6 & 6 & 423 & Spirals & 1.13 & 65 & 456 & 2.5 & 36.00 & 3490 \\
\hline \multirow{4}{*}{$\begin{array}{l}\text { Wang et } \\
\text { al. [21] }\end{array}$} & $a$ & 500 & 1500 & 12 & 1.6 & 12 & 295 & Spirals & 1.20 & 52 & 310 & 2.5 & 28.00 & 38.0 \\
\hline & $b$ & 500 & 1500 & 12 & 1.6 & 12 & 295 & Spirals & 1.20 & 52 & 340 & 2.5 & 31.00 & 48.0 \\
\hline & c & 500 & 1500 & 12 & 1.6 & 12 & 295 & Spirals & 1.20 & 52 & 340 & 2.5 & 33.00 & 47.0 \\
\hline & 1 & 500 & 1500 & 12 & 1.6 & 12 & 295 & Spirals & 1.20 & 41 & 340 & 2.5 & 28.00 & 51.0 \\
\hline \multirow{15}{*}{$\begin{array}{c}\text { Mander, } \\
\text { Priestley, } \\
\text { and Park } \\
{[7]}\end{array}$} & 2 & 500 & 1500 & 12 & 1.6 & 12 & 295 & Spirals & 1.20 & 69 & 340 & 2.5 & 28.00 & 46.0 \\
\hline & 3 & 500 & 1500 & 12 & 1.6 & 12 & 295 & Spirals & 1.20 & 103 & 340 & 2.5 & 28.00 & 40.0 \\
\hline & 4 & 500 & 1500 & 12 & 1.6 & 12 & 295 & Spirals & 1.00 & 119 & 320 & 2.5 & 28.00 & 36.0 \\
\hline & 5 & 500 & 1500 & 12 & 1.6 & 12 & 295 & Spirals & 1.00 & 36 & 320 & 2.5 & 28.00 & 47.0 \\
\hline & 6 & 500 & 1500 & 12 & 1.6 & 12 & 295 & Spirals & 1.60 & 93 & 307 & 2.5 & 28.00 & 46.0 \\
\hline & 7 & 500 & 1500 & 12 & 2.8 & 8 & 296 & Spirals & 1.20 & 52 & 340 & 2.5 & 31.00 & 52.0 \\
\hline & 8 & 500 & 1500 & 12 & 2.4 & 11 & 260 & Spirals & 1.20 & 52 & 340 & 2.5 & 27.00 & 49.0 \\
\hline & 9 & 500 & 1500 & 12 & 2.0 & 16 & 286 & Spirals & 1.20 & 52 & 340 & 2.5 & 31.00 & 52.0 \\
\hline & 10 & 500 & 1500 & 12 & 1.6 & 24 & 295 & Spirals & 1.20 & 52 & 340 & 2.5 & 27.00 & 50.0 \\
\hline & 11 & 500 & 1500 & 12 & 1.6 & 36 & 295 & Spirals & 1.20 & 52 & 340 & 2.5 & 27.00 & 54.0 \\
\hline & 12 & 500 & 1500 & 12 & 1.6 & 24 & 360 & Spirals & 1.20 & 52 & 340 & 2.5 & 31.00 & 52.0 \\
\hline & C2H2LOM & 204 & 612 & 12 & 1.0 & 6 & 312 & Stirrups & 0.60 & 60 & 397 & 1.5 & 24.50 & 30.1 \\
\hline & C2H2LOM & 204 & 612 & 12 & 1.0 & 6 & 312 & Stirrups & 0.60 & 60 & 397 & 1.5 & 24.50 & 30.1 \\
\hline & C2H2LOM & 204 & 612 & 12 & 1.0 & 6 & 312 & Stirrups & 0.60 & 60 & 397 & 1.5 & 24.50 & 30.1 \\
\hline & C2H2LOM & 204 & 612 & 12 & 1.0 & 6 & 312 & Stirrups & 0.60 & 60 & 397 & 1.5 & 24.50 & 30.1 \\
\hline
\end{tabular}

analysis, it is concluded that only the models of Samaan et al. [10], Saafi et al. [14], and Spoelstra and Monti [15] are not significantly different from the experimental results. Therefore, it is possible to accept the hypothesis that only these models can predict a strength of confined concrete equal to the values observed in tests at a significance level of $10 \%$ (Figure 6 ). When comparing the results predicted by these models with the experimental results for this data set of columns tested, a correlation coefficient that ranges from 0.63 to 0.75 is obtained, as shown in Figure 7 , and the best correlation is presented by the model of Spoelstra and Monti [15] (Figure 7 (c)).

\subsubsection{Columns strengthened only with transverse reinforcement}

The database used for the second analysis contains 25 circular columns reinforced with transverse and longitudinal reinforcements

\section{Table 7}

Comparison between theoretical and experimental results for columns strengthened with transverse reinforcement

\begin{tabular}{ccccc}
\hline & \multicolumn{4}{c}{$\mathbf{F}_{\mathrm{u}, \text { heor }} / \mathrm{F}_{\mathrm{u} \text { exp }}$} \\
\cline { 2 - 5 } Reference & $\begin{array}{c}\text { Cusson } \\
\text { and } \\
\text { Paultre } \\
\text { [2] }\end{array}$ & $\begin{array}{c}\text { Saatcioglu } \\
\text { and } \\
\text { Razvi [3] }\end{array}$ & $\begin{array}{c}\text { Frangou } \\
\text { et al. [4] }\end{array}$ & $\begin{array}{c}\text { fib Model } \\
\text { Code 2010 } \\
\text { [5] }\end{array}$ \\
\hline Mean & 0.90 & 1.02 & 0.88 & 0.97 \\
CV & 0.06 & 0.08 & 0.06 & 0.08 \\
\hline
\end{tabular}

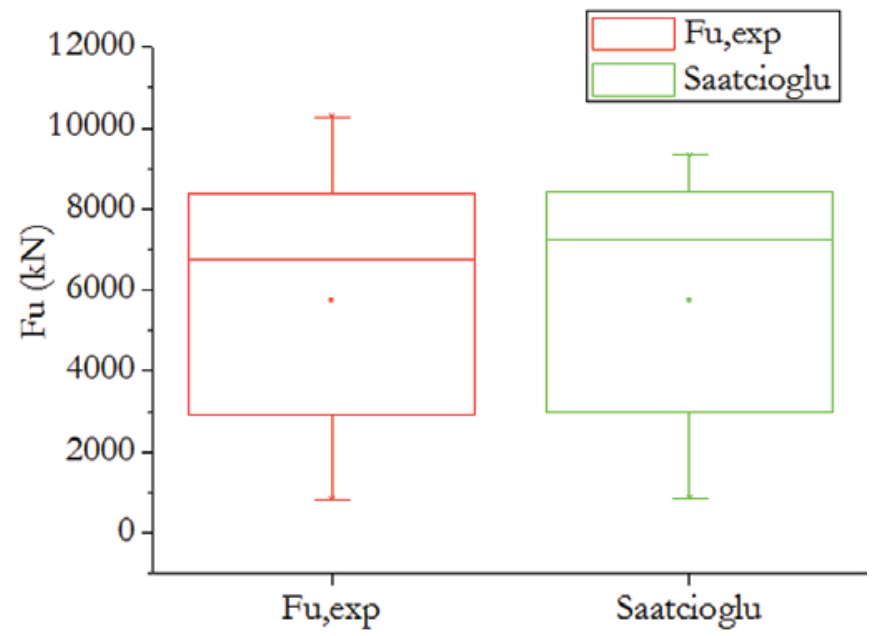

Figure 8

Variability of Saatcioglu and Razvi's model [3] when compared to experimental values

\section{Table 8}

Results of student's t-test for columns strengthened with transverse reinforcement. t-critical $=1.71088$

\begin{tabular}{cc}
\hline Reference & $\mathbf{t}$ \\
\hline Cusson and Paultre [2] & 5.40745 \\
Saatcioglu and Razvi [3] & -0.02044 \\
Frangou et al. [4] & 5.91667 \\
fib Model Code 2010 [5] & 1.99189 \\
\hline
\end{tabular}




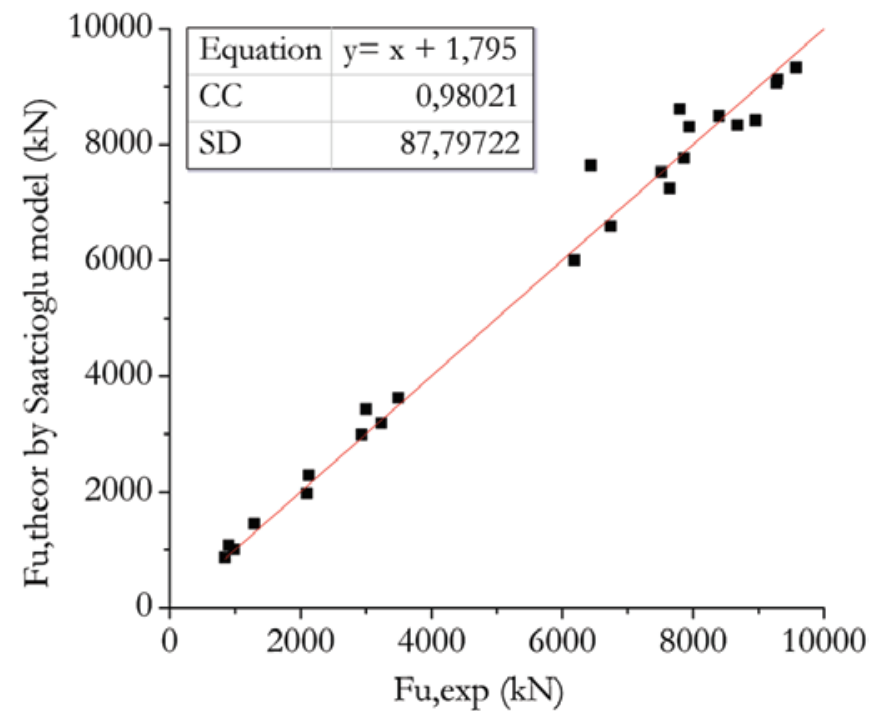

\section{Figure 9}

Comparison of theoretical and experimental results of ultimate load of the column $\left(\mathrm{F}_{\mathrm{u}}\right)$ for Saatcioglu and Razvi's model [3]. CC: Correlation coefficient; SD: Standard deviation

(Table 6). Two columns were tested by Carrazedo [6], four by Eid, Roy, and Paultre [20], four by Wang et al. [21], and fifteen by Mander, Pristley, and Park [7]. All columns were short, with diameters varying between 190 and $500 \mathrm{~mm}$ and concrete compressive strength ranging from 24.5 to $36 \mathrm{MPa}$. The results of this analysis are presented in Table 7. The columns' resistance in this analysis was evaluated by adding the confined concrete resistance and the resistance due to the longitudinal reinforcement. The contribution of the concrete cover of the column was disregarded.

The comparison shows that all four design models predicted the experimental columns' strength with a difference of less than $12 \%$ and a coefficient of variation of around $8 \%$. Saatcioglu and Razvi's [3] overestimated the resistance, since the authors considered the coefficient of confinement effectiveness to be equal to 1.0 for circular columns. However, this model showed a difference from the experimental results of only $2 \%$.

From the bilateral paired Student's t-test with a level of significance $(\alpha)$ of $10 \%$ (Table 8 ), it is concluded that only the prediction by Saatcioglu and Razvi's model [3] is not significantly different from the experimental results. Thus, only this model can predict the strength of reinforced concrete column equal to the value observed in tests of columns confined with transverse reinforcement at a significance level of $10 \%$ (Figure 8 ). When comparing the results predicted by Saatcioglu and Razvi's model [3] with the experimental results for this data set of columns, a correlation coefficient of 0.98 is obtained (Figure 9).

\subsubsection{Columns strengthened with CFRP and transverse reinforcement}

The database for this analysis contains 63 columns, that is, six columns tested by Huang et al. [23], four tested by Carrazedo [6], thirteen tested by Eid, Roy and Paultre [20], fourteen tested by Lee et al. [22], nineteen tested by Yin et al. [24], and eight tested by Wang et al. [21]. All columns were short, with diameters varying from 150 to $305 \mathrm{~mm}$ and compressive concrete strength varying from 24.5 to $50.8 \mathrm{MPa}$. Six columns were strengthened with GFRP sheet wrapping and 57 with CFRP sheet wrapping. Moreover, 12 columns were made with conventional stirrups and 51 were made with circular spiral reinforcements (Table 9). For this analysis, the theoretical resistance of strengthened columns was calculated using Equation (16). Four design models with confinement by transverse reinforcement, shown in Subsection 2.1, were combined with ten models of confinement by FRP, shown in Subsection 2.2, generating a total of 40 combinations. Moreover, Machado's proposal [9] of considering simultaneous confinement by CRFP and stirrups was analyzed. The results are shown in Table 10. In this analysis, the columns' strength was
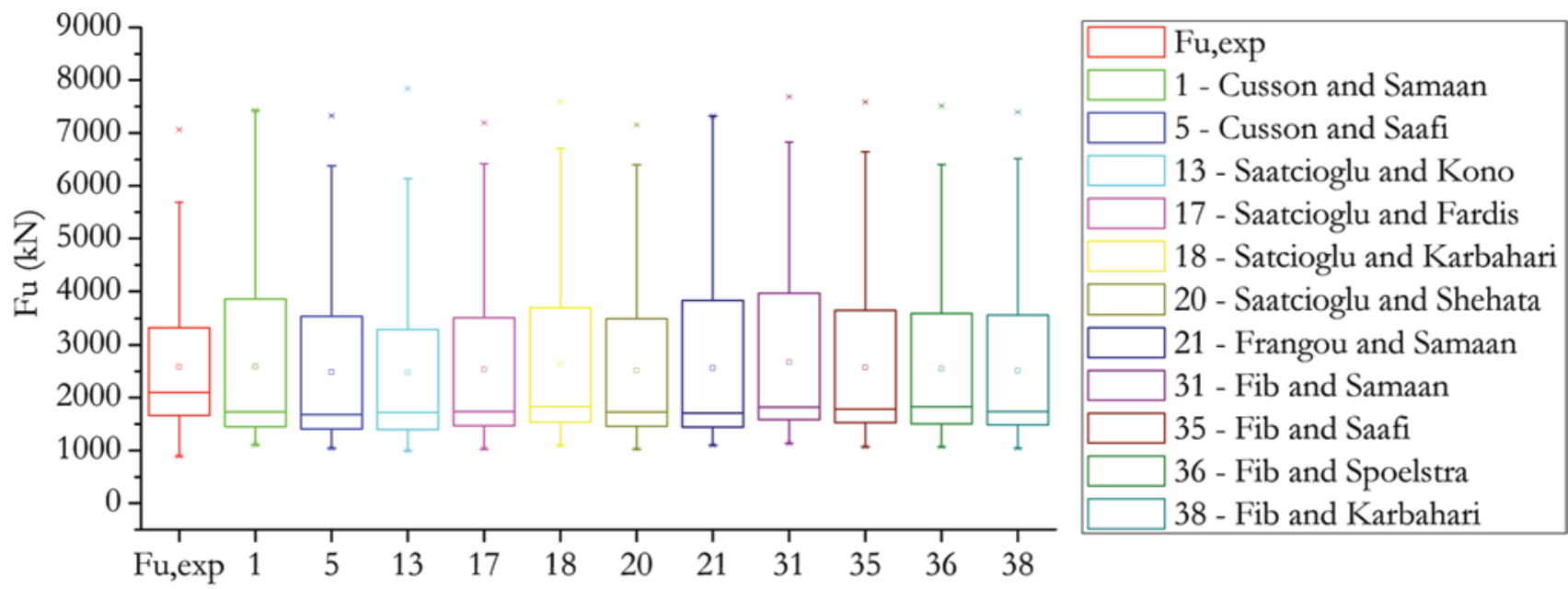

Figure 10

Variability of confinement models with FRP and transverse reinforcement when compared to experimental values. 
evaluated by adding the resistance due to confined concrete to the resistance of the longitudinal reinforcement.

The general view shows that the results of all 41 analyses were close to the values obtained from the tests. However, all combinations showed a coefficient of variation greater than $20 \%$.

From the results of the bilateral paired Student's t-test with a level of significance $(\alpha)$ of $10 \%$ shown in Table 11 , it can be concluded that the predicted and experimentally determined resistance were not significantly different in eleven combinations (Table 12). Thus, only these models can predict the strength of a reinforced concrete column equal to the value observed in tests of columns confined with transverse reinforcement and CFRP sheet wrapping at a significance level of $10 \%$ (Figure 10). When comparing the results predicted by these eleven models with the experimental results for this data set of columns, a correlation coefficient that varies from 0.88 to 0.92 is obtained (Figure 11). The best correlation is observed from the combination of the fib Model Code 2010 [5] and Spoelstra and Monti's model [15], that is, combination number 36 (Figure $11(j)$ ). Moreover, the ratio between the axial strength predicted by the eleven models and the experimental results of the columns in the data set ranged from 0.93 to 1.00 .

The proposal of Machado [9] overestimated the resistance of the dataset columns, on average, by $6 \%$. When it was analyzed statistically, this proposal was significantly different from the experimental results at a significance level of $10 \%$. Therefore, the combinations of strengthen- ing systems shown in Table 12 were considered more efficient than Machado's proposal [9] in the prediction of the resistance of columns strengthened by transverse reinforcement and CFRP sheet wrapping.

\section{Conclusions}

In this paper, some of main models used for strengthening of concrete columns with concrete jacket or wrapping with CFRP sheets were analyzed. They were applied to a database with 135 columns tested in the laboratory to evaluate the effectiveness of the design models and the results were statistically analyzed. The main conclusions are as follows:

- For strengthening with a concrete jacket, the design models proposed by Cusson and Paultre [2], Saatcioglu and Razvi [3], Frangou et al. [4], and the fib Model Code 2010 [5] showed good correlation with the experimental results. However, when they were applied to columns confined with transverse reinforcement (Subsection 3.2.2), only Saatcioglu and Razvi's model [3] was efficient, showing a correlation coefficient of 0.98 with the database columns;

- For columns wrapped exclusively with CFRP sheets, the models of Samaan et al. [10], Saafi et al. [14], and Spoelstra and Monti [15] predicted the experimental results best. Spoelstra and Monti's model [15] showed a better correlation with the strength of the columns in the database;

\section{Table 9}

Database of reinforced columns confined with FRP and transverse reinforcement (part 1)

\begin{tabular}{|c|c|c|c|c|c|c|c|c|c|c|c|c|c|c|c|c|c|}
\hline \multirow{2}{*}{ Reference } & \multirow{2}{*}{ Model } & \multicolumn{4}{|c|}{$\begin{array}{l}\text { Dimensions of column } \\
\text { and concrete strength }\end{array}$} & \multicolumn{5}{|c|}{ FRP } & \multicolumn{3}{|c|}{$\begin{array}{l}\text { Longitudinal } \\
\text { reinforcement }\end{array}$} & \multicolumn{4}{|c|}{ Transverse reinforcement } \\
\hline & & $\begin{array}{c}\mathrm{D} \\
(\mathrm{mm})\end{array}$ & $\begin{array}{c}\mathrm{H} \\
(\mathrm{mm})\end{array}$ & $\begin{array}{c}\mathrm{c} \\
(\mathrm{cm})\end{array}$ & $\begin{array}{c}f_{c} \\
(M P a)\end{array}$ & $\begin{array}{l}\text { Fiber } \\
\text { type }\end{array}$ & $\begin{array}{c}t_{f} \\
(\mathrm{~mm})\end{array}$ & $\begin{array}{c}\xi_{\mathrm{f}} \\
(\% \circ)\end{array}$ & $\begin{array}{c}E_{f} \\
(\mathrm{MPa})\end{array}$ & $\mathrm{n}$ & $\begin{array}{c}\phi_{1} \\
(\mathrm{~cm})\end{array}$ & $n^{\circ}$ & $\begin{array}{c}f_{y, 1} \\
(M P a)\end{array}$ & Type & $\begin{array}{c}\phi_{t} \\
(\mathrm{~cm})\end{array}$ & $\begin{array}{c}\mathrm{s} \\
(\mathrm{mm})\end{array}$ & $\begin{array}{r}f_{y, t} \\
(M P a)\end{array}$ \\
\hline \multirow{4}{*}{$\begin{array}{l}\text { Carrazedo } \\
{[6]}\end{array}$} & C1S50 & 190 & 570 & 1.5 & 26.16 & CFRP & 0.130 & 11.00 & 218950 & 1 & 0.8 & 6 & 554.8 & Spirals & 0.50 & 50 & 756 \\
\hline & $\mathrm{C} 2 \mathrm{~S} 50$ & 190 & 570 & 1.5 & 26.16 & CFRP & 0.130 & 8.78 & 218950 & 2 & 0.8 & 6 & 554.8 & Spirals & 0.50 & 50 & 756 \\
\hline & $\mathrm{C} 1 S 25$ & 190 & 570 & 1.5 & 28.86 & CFRP & 0.130 & 10.63 & 218950 & 1 & 0.8 & 6 & 554.8 & Spirals & 0.50 & 25 & 756 \\
\hline & $\mathrm{C} 2 \mathrm{~S} 25$ & 190 & 570 & 1.5 & 28.86 & CFRP & 0.130 & 10.65 & 218950 & 2 & 0.8 & 6 & 554.8 & Spirals & 0.50 & 25 & 756 \\
\hline \multirow{13}{*}{$\begin{array}{l}\text { Eid, Roy, and } \\
\text { Paultre [20] }\end{array}$} & A5NP2C & 303 & 1200 & 2.5 & 29.40 & CFRP & 0.381 & 13.40 & 78000 & 2 & 1.6 & 6 & 423 & Stirrups & 0.95 & 150 & 602 \\
\hline & A3NP2C & 303 & 1200 & 2.5 & 31.70 & CFRP & 0.381 & 13.40 & 78000 & 2 & 1.6 & 6 & 550 & Stirrups & 0.95 & 70 & 602 \\
\hline & A1NP2C & 303 & 1200 & 2.5 & 31.70 & CFRP & 0.381 & 13.40 & 78000 & 2 & 1.6 & 6 & 486.5 & Stirrups & 0.95 & 45 & 602 \\
\hline & C4NP2C & 303 & 1200 & 2.5 & 31.70 & CFRP & 0.381 & 13.40 & 78000 & 2 & 1.6 & 6 & 423 & Stirrups & 1.13 & 100 & 456 \\
\hline & C4NIP2C & 303 & 1200 & 2.5 & 36.00 & CFRP & 0.381 & 13.40 & 78000 & 2 & 1.6 & 6 & 423 & Spirals & 1.13 & 100 & 456 \\
\hline & C4NP4C & 303 & 1200 & 2.5 & 31.70 & CFRP & 0.381 & 13.40 & 78000 & 4 & 1.6 & 6 & 423 & Spirals & 1.13 & 100 & 456 \\
\hline & B4NP2C & 303 & 1200 & 2.5 & 31.70 & CFRP & 0.381 & 13.40 & 78000 & 2 & 1.6 & 6 & 550 & Stirrups & 1.13 & 100 & 456 \\
\hline & C4MP2C & 303 & 1200 & 2.5 & 50.80 & CFRP & 0.381 & 13.40 & 78000 & 2 & 1.6 & 6 & 423 & Spirals & 1.13 & 100 & 456 \\
\hline & C2NP2C & 303 & 1200 & 2.5 & 31.70 & CFRP & 0.381 & 13.40 & 78000 & 2 & 1.6 & 6 & 423 & Spirals & 1.13 & 65 & 456 \\
\hline & C2NIP2C & 303 & 1200 & 2.5 & 36.00 & CFRP & 0.381 & 13.40 & 78000 & 2 & 1.6 & 6 & 423 & Spirals & 1.13 & 65 & 456 \\
\hline & C2NIP4C & 303 & 1200 & 2.5 & 36.00 & CFRP & 0.381 & 13.40 & 78000 & 4 & 1.6 & 6 & 423 & Spirals & 1.13 & 65 & 456 \\
\hline & $\mathrm{C} 2 \mathrm{MP} 2 \mathrm{C}$ & 303 & 1200 & 2.5 & 50.80 & CFRP & 0.381 & 13.40 & 78000 & 2 & 1.6 & 6 & 423 & Spirals & 1.13 & 65 & 456 \\
\hline & C2MP4C & 303 & 1200 & 2.5 & 50.80 & CFRP & 0.381 & 13.40 & 78000 & 4 & 1.6 & 6 & 423 & Spirals & 1.13 & 65 & 456 \\
\hline \multirow{6}{*}{$\begin{array}{l}\text { Huang et al. } \\
\text { [23] }\end{array}$} & PIS1 & 150 & 300 & 0 & 30.04 & GFRP & 0.436 & 16.00 & 60800 & 1 & - & - & - & Spirals & 0.80 & 25 & 356 \\
\hline & P2S1 & 150 & 300 & 0 & 30.04 & GFRP & 0.436 & 16.00 & 60800 & 2 & - & - & - & Spirals & 0.80 & 25 & 356 \\
\hline & P3S1 & 150 & 300 & 0 & 30.04 & GFRP & 0.436 & 16.00 & 60800 & 3 & - & - & - & Spirals & 0.80 & 25 & 356 \\
\hline & PIS2 & 150 & 300 & 0 & 30.04 & GFRP & 0.436 & 16.00 & 60800 & 1 & - & - & - & Spirals & 0.80 & 50 & 356 \\
\hline & P2S2 & 150 & 300 & 0 & 30.04 & GFRP & 0.436 & 16.00 & 60800 & 2 & - & - & - & Spirals & 0.80 & 50 & 356 \\
\hline & P3S2 & 150 & 300 & 0 & 30.04 & GFRP & 0.436 & 16.00 & 60800 & 3 & - & - & - & Spirals & 0.80 & 50 & 356 \\
\hline
\end{tabular}


From the 41 combinations of the reinforced column strengthened with FRP and transverse reinforcement analyzed, only eleven combinations predicted a resistance that did not differ statistically from the resistance of columns evaluated in the data set (Table 12). The best correlation was obtained for the combination of the fib Model Code 2010 [5] and Spoelstra and Monti [15],

- For column strengthening with FRP and transverse reinforce- ment, it was shown that there is simultaneous confinement due to both materials. Moreover, the hypothesis that the confined concrete strength can be obtained by adding the parcels of resistance due to CFRP sheet wrapping and due to transverse reinforcement separately was more effective than the hypothesis that the confined concrete resistance would be obtained from the sum of the lateral pressure due to the CFRP and transverse reinforcement.

\section{Table 9}

Database of reinforced columns confined with FRP and transverse reinforcement (part 2)

\begin{tabular}{|c|c|c|c|c|c|c|c|c|c|c|c|c|c|c|c|c|c|}
\hline \multirow{2}{*}{ Reference } & \multirow{2}{*}{ Model } & \multicolumn{4}{|c|}{$\begin{array}{l}\text { Dimensions of column } \\
\text { and concrete strength }\end{array}$} & \multicolumn{5}{|c|}{ FRP } & \multicolumn{3}{|c|}{$\begin{array}{l}\text { Longitudinal } \\
\text { reinforcement }\end{array}$} & \multicolumn{4}{|c|}{ Transverse reinforcement } \\
\hline & & $\begin{array}{c}\mathrm{D} \\
(\mathrm{mm})\end{array}$ & $\underset{(\mathrm{mm})}{\mathrm{H}}$ & $\begin{array}{c}\mathrm{c} \\
(\mathrm{cm})\end{array}$ & $\begin{array}{c}f_{c} \\
(\mathrm{MPa})\end{array}$ & $\begin{array}{l}\text { Fiber } \\
\text { type }\end{array}$ & $\left(\begin{array}{c}t_{f} \\
(\mathrm{~mm})\end{array}\right.$ & $\begin{array}{c}\xi_{f} \\
(\% \circ)\end{array}$ & $\begin{array}{c}E_{f} \\
(\mathrm{MPa})\end{array}$ & $\mathrm{n}$ & $\begin{array}{c}\phi_{1} \\
(\mathrm{~cm})\end{array}$ & $n^{0}$ & $\begin{array}{c}f_{y, 1} \\
(M P a)\end{array}$ & Type & $\begin{array}{c}\phi_{\dagger} \\
(\mathrm{cm})\end{array}$ & $\underset{(\mathrm{mm})}{\mathrm{s}}$ & $\begin{array}{c}f_{\mathrm{y}, \mathrm{t}} \\
(\mathrm{MPa})\end{array}$ \\
\hline \multirow{14}{*}{$\begin{array}{l}\text { Lee et al. } \\
\quad[22]\end{array}$} & S6Fl & 150 & 300 & 0.725 & 36.20 & CFRP & 0.110 & 18.04 & 250000 & 1 & - & - & - & Spirals & 0.55 & 60 & 569.6 \\
\hline & S6F2 & 150 & 300 & 0.725 & 36.20 & CFRP & 0.110 & 18.04 & 250000 & 2 & - & - & - & Spirals & 0.55 & 60 & 569.6 \\
\hline & S6F4 & 150 & 300 & 0.725 & 36.20 & CFRP & 0.110 & 18.04 & 250000 & 4 & - & - & - & Spirals & 0.55 & 60 & 569.6 \\
\hline & S6F5 & 150 & 300 & 0.725 & 36.20 & CFRP & 0.110 & 18.04 & 250000 & 5 & - & - & - & Spirals & 0.55 & 60 & 569.6 \\
\hline & S4F1 & 150 & 300 & 0.725 & 36.20 & CFRP & 0.110 & 18.04 & 250000 & 1 & - & - & - & Spirals & 0.55 & 40 & 569.6 \\
\hline & S4F2 & 150 & 300 & 0.725 & 36.20 & CFRP & 0.110 & 18.04 & 250000 & 2 & - & - & - & Spirals & 0.55 & 40 & 569.6 \\
\hline & S4F3 & 150 & 300 & 0.725 & 36.20 & CFRP & 0.110 & 18.04 & 250000 & 3 & - & - & - & Spirals & 0.55 & 40 & 569.6 \\
\hline & S4F4 & 150 & 300 & 0.725 & 36.20 & CFRP & 0.110 & 18.04 & 250000 & 4 & - & - & - & Spirals & 0.55 & 40 & 569.6 \\
\hline & S4F5 & 150 & 300 & 0.725 & 36.20 & CFRP & 0.110 & 18.04 & 250000 & 5 & - & - & - & Spirals & 0.55 & 40 & 569.6 \\
\hline & $\mathrm{S} 2 \mathrm{Fl}$ & 150 & 300 & 0.725 & 36.20 & CFRP & 0.110 & 18.04 & 250000 & 1 & - & - & - & Spirals & 0.55 & 20 & 569.6 \\
\hline & S2F2 & 150 & 300 & 0.725 & 36.20 & CFRP & 0.110 & 18.04 & 250000 & 2 & - & - & - & Spirals & 0.55 & 20 & 569.6 \\
\hline & S2F3 & 150 & 300 & 0.725 & 36.20 & CFRP & 0.110 & 18.04 & 250000 & 3 & - & - & - & Spirals & 0.55 & 20 & 569.6 \\
\hline & S2F4 & 150 & 300 & 0.725 & 36.20 & CFRP & 0.110 & 18.04 & 250000 & 4 & - & - & - & Spirals & 0.55 & 20 & 569.6 \\
\hline & S2F5 & 150 & 300 & 0.725 & 36.20 & CFRP & 0.110 & 18.04 & 250000 & 5 & - & - & - & Spirals & 0.55 & 20 & 569.6 \\
\hline \multirow{18}{*}{$\begin{array}{l}\text { Yin et al. } \\
{[24]}\end{array}$} & 1L-50-N1 & 150 & 300 & 0.5 & 30.60 & CFRP & 0.167 & 15.00 & 213000 & 1 & - & - & - & Spirals & 0.60 & 50 & 335 \\
\hline & 1L-50-N2 & 150 & 300 & 0.5 & 30.60 & CFRP & 0.167 & 15.00 & 213000 & 1 & - & - & - & Spirals & 0.60 & 50 & 335 \\
\hline & 1L-50-N3 & 150 & 300 & 0.5 & 30.60 & CFRP & 0.167 & 15.00 & 213000 & 1 & - & - & - & Spirals & 0.60 & 50 & 335 \\
\hline & 1L-25-N1 & 150 & 300 & 0.5 & 30.60 & CFRP & 0.167 & 15.00 & 213000 & 1 & - & - & - & Spirals & 0.60 & 25 & 335 \\
\hline & 1L-25-N2 & 150 & 300 & 0.5 & 30.60 & CFRP & 0.167 & 15.00 & 213000 & 1 & - & - & - & Spirals & 0.60 & 25 & 335 \\
\hline & 1L-25-N3 & 150 & 300 & 0.5 & 30.60 & CFRP & 0.167 & 15.00 & 213000 & 1 & - & - & - & Spirals & 0.60 & 25 & 335 \\
\hline & 2L-50-N1 & 150 & 300 & 0.5 & 30.60 & CFRP & 0.167 & 15.00 & 213000 & 2 & - & - & - & Spirals & 0.60 & 50 & 335 \\
\hline & 2L-50-N2 & 150 & 300 & 0.5 & 30.60 & CFRP & 0.167 & 15.00 & 213000 & 2 & - & - & - & Spirals & 0.60 & 50 & 335 \\
\hline & 2L-50-N3 & 150 & 300 & 0.5 & 30.60 & CFRP & 0.167 & 15.00 & 213000 & 2 & - & - & - & Spirals & 0.60 & 50 & 335 \\
\hline & 2L-25-N1 & 150 & 300 & 0.5 & 30.60 & CFRP & 0.167 & 15.00 & 213000 & 2 & - & - & - & Spirals & 0.60 & 25 & 335 \\
\hline & 2L-25-N2 & 150 & 300 & 0.5 & 30.60 & CFRP & 0.167 & 15.00 & 213000 & 2 & - & - & - & Spirals & 0.60 & 25 & 335 \\
\hline & 2L-25-N3 & 150 & 300 & 0.5 & 30.60 & CFRP & 0.167 & 15.00 & 213000 & 2 & - & - & - & Spirals & 0.60 & 25 & 335 \\
\hline & 3L-50-N1 & 150 & 300 & 0.5 & 30.60 & CFRP & 0.167 & 15.00 & 213000 & 3 & - & - & - & Spirals & 0.60 & 50 & 335 \\
\hline & 3L-50-N2 & 150 & 300 & 0.5 & 30.60 & CFRP & 0.167 & 15.00 & 213000 & 3 & - & - & - & Spirals & 0.60 & 50 & 335 \\
\hline & 3L-50-N3 & 150 & 300 & 0.5 & 30.60 & CFRP & 0.167 & 15.00 & 213000 & 3 & - & - & - & Spirals & 0.60 & 50 & 335 \\
\hline & 3L-25-N1 & 150 & 300 & 0.5 & 30.60 & CFRP & 0.167 & 15.00 & 213000 & 3 & - & - & - & Spirals & 0.60 & 25 & 335 \\
\hline & $3 L-25-N 2$ & 150 & 300 & 0.5 & 30.60 & CFRP & 0.167 & 15.00 & 213000 & 3 & - & - & - & Spirals & 0.60 & 25 & 335 \\
\hline & 3L-25-N3 & 150 & 300 & 0.5 & 30.60 & CFRP & 0.167 & 15.00 & 213000 & 3 & - & - & - & Spirals & 0.60 & 25 & 335 \\
\hline \multirow{8}{*}{$\begin{array}{l}\text { Wang et al. } \\
{[21]}\end{array}$} & CIHILIM & 305 & 915 & 2.1 & 24.50 & CFRP & 0.167 & 17.79 & 244000 & 1 & 1.2 & 8 & 340.0 & Stirrups & 0.60 & 80 & 397 \\
\hline & ClH1L2M & 305 & 915 & 2.1 & 24.50 & CFRP & 0.167 & 17.79 & 244000 & 2 & 1.2 & 8 & 340.0 & Stirrups & 0.60 & 80 & 397 \\
\hline & $\mathrm{ClH} 2 \mathrm{~L} 1 \mathrm{M}$ & 305 & 915 & 2.1 & 24.50 & CFRP & 0.167 & 17.79 & 244000 & 1 & 1.2 & 8 & 340.0 & Stirrups & 0.60 & 40 & 397 \\
\hline & $\mathrm{C} 1 \mathrm{H} 2 \mathrm{~L} 2 \mathrm{M}$ & 305 & 915 & 2.1 & 24.50 & CFRP & 0.167 & 17.79 & 244000 & 2 & 1.2 & 8 & 340.0 & Stirrups & 0.60 & 40 & 397 \\
\hline & C2HILIM & 204 & 612 & 1.5 & 24.50 & CFRP & 0.167 & 17.79 & 244000 & 1 & 1 & 6 & 312.0 & Stirrups & 0.60 & 120 & 397 \\
\hline & $\mathrm{C} 2 \mathrm{H} 1 \mathrm{~L} 2 \mathrm{M}$ & 204 & 612 & 1.5 & 24.50 & CFRP & 0.167 & 17.79 & 244000 & 2 & 1 & 6 & 312.0 & Stirrups & 0.60 & 120 & 397 \\
\hline & C2H2L1M & 204 & 612 & 1.5 & 24.50 & CFRP & 0.167 & 17.79 & 244000 & 1 & 1 & 6 & 312.0 & Stirrups & 0.60 & 60 & 397 \\
\hline & C2H2L2M & 204 & 612 & 1.5 & 24.50 & CFRP & 0.167 & 17.79 & 244000 & 2 & 1 & 6 & 312.0 & Stirrups & 0.60 & 60 & 397 \\
\hline
\end{tabular}




\section{Notation}

$\begin{array}{ll}\text { AFRP } & \text { Aramid Fiber Reinforced Polymers, } \\ A_{c, n} & \text { Area of core of section within center lines of transverse reinforcement, } \\ A_{g} & \text { Gross area of column, } \\ A_{s, t x} & \text { Total area of transverse reinforcement parallel to y-axis, } \\ A_{s, t y} & \text { Total area of transverse reinforcement parallel to x-axis, } \\ A_{s, l} & \text { Total area of longitudinal reinforcement of the column, } \\ A_{s, t} & \text { Area of the transverse reinforcement, }\end{array}$

b Rectangular column width,

$b_{c} \quad$ Distance between centers of longitudinal bars,

c Concrete cover,

$c_{x} \quad$ Core dimension of the column perpendicular to the $x$ direction, measured between centers of transverse reinforcement,

$c_{y} \quad$ Core dimension of the column perpendicular to the y direction, measured between centers of transverse reinforcement, CFRP Carbon Fiber Reinforced Polymers,

d. Diameter of circular stirrups or spiral between bar centers,

Table 10

Comparison between the theoretical and experimental results for columns strengthened with FRP and transverse reinforcement

\begin{tabular}{|c|c|c|c|}
\hline Comb. & References & Mean & CV \\
\hline 1 & Cusson and Paultre [2] and Samaan et al. [10] & 0.97 & 0.22 \\
\hline 2 & Cusson and Paultre [2] and Miyauchi et al. [11] & 1.05 & 0.20 \\
\hline 3 & Cusson and Paultre [2] and Kono et al. [12] & 0.84 & 0.24 \\
\hline 4 & Cusson and Paultre [2] and Toutanji [13] & 1.13 & 0.20 \\
\hline 5 & Cusson and Paultre [2] and Saafi et al. [14] & 0.93 & 0.21 \\
\hline 6 & Cusson and Paultre [2] and Spoelstra and Monti [15] & 0.93 & 0.20 \\
\hline 7 & Cusson and Paultre [2] and Fardis and Khalili [16] & 0.86 & 0.21 \\
\hline 8 & Cusson and Paultre [2] and Karbhari and Eckel [17] & 0.91 & 0.21 \\
\hline 9 & Cusson and Paultre [2] and Mirmiran and Shahawy [18] & 0.80 & 0.26 \\
\hline 10 & Cusson and Paultre [2] and Shehata, Carneiro, and Shehata [19] & 0.86 & 0.21 \\
\hline 11 & Saatcioglu and Razvi [3] and Samaan et al. [10] & 1.06 & 0.21 \\
\hline 12 & Saatcioglu and Razvi [3] and Miyauchi et al. [11] & 1.15 & 0.20 \\
\hline 13 & Saatcioglu and Razvi [3] and Kono et al. [12] & 0.93 & 0.24 \\
\hline 14 & Saatcioglu and Razvi [3] and Toutanji [13] & 1.22 & 0.20 \\
\hline 15 & Saatcioglu and Razvi [3] and Saafi et al. [14] & 1.02 & 0.21 \\
\hline 16 & Saatcioglu and Razvi [3] and Spoelstra and Monti [15] & 1.02 & 0.20 \\
\hline 17 & Saatcioglu and Razvi [3] and Fardis and Khalili [16] & 0.95 & 0.21 \\
\hline 18 & Saatcioglu and Razvi [3] and Karbhari and Eckel [17] & 1.00 & 0.21 \\
\hline 19 & Saatcioglu and Razvi [3] and Mirmiran and Shahawy [18] & 0.89 & 0.26 \\
\hline 20 & Saatcioglu and Razvi [3] and Shehata, Carneiro, and Shehata [19] & 0.95 & 0.21 \\
\hline 21 & Frangou et al. [4] and Samaan et al. [10] & 0.96 & 0.22 \\
\hline 22 & Frangou et al. [4] and Miyauchi et al. [11] & 1.04 & 0.21 \\
\hline 23 & Frangou et al. [4] and Kono et al. [12] & 0.83 & 0.24 \\
\hline 24 & Frangou et al. [4] and Toutanji [13] & 1.12 & 0.20 \\
\hline 25 & Frangou et al. [4] and Saafi et al. [14] & 0.92 & 0.22 \\
\hline 26 & Frangou et al. [4] and Spoelstra and Monti [15] & 0.92 & 0.20 \\
\hline 27 & Frangou et al. [4] and Fardis and Khalili [16] & 0.85 & 0.22 \\
\hline 28 & Frangou et al. [4] and Karbhari and Eckel [17] & 0.90 & 0.22 \\
\hline 29 & Frangou et al. [4] and Mirmiran and Shahawy [18] & 0.79 & 0.26 \\
\hline 30 & Frangou et al. [4] and Shehata, Carneiro, and Shehata [19] & 0.85 & 0.22 \\
\hline 31 & fib Model Code 2010 [5] and Samaan et al. [10] & 1.00 & 0.21 \\
\hline 32 & fib Model Code 2010 [5] and Miyauchi et al. [11] & 1.09 & 0.19 \\
\hline 33 & fib Model Code 2010 [5] and Kono et al. [12] & 0.87 & 0.23 \\
\hline 34 & fib Model Code 2010 [5] and Toutanji [13] & 1.16 & 0.19 \\
\hline 35 & fib Model Code 2010 [5] and Saafi et al. [14] & 0.97 & 0.21 \\
\hline 36 & fib Model Code 2010 [5] and Spoelstra and Monti [15] & 0.97 & 0.19 \\
\hline 37 & fib Model Code 2010 [5] and Fardis and Khalili [16] & 0.90 & 0.21 \\
\hline 38 & fib Model Code 2010 [5] and Karbhari and Eckel [17] & 0.94 & 0.21 \\
\hline 39 & fib Model Code 2010 [5] and Mirmiran and Shahawy [18] & 0.83 & 0.25 \\
\hline 40 & fib Model Code 2010 [5] and Shehata, Carneiro, and Shehata [19] & 0.89 & 0.21 \\
\hline 41 & Machado [9] & 1.06 & 0.23 \\
\hline
\end{tabular}


d Diameter of the concrete section confined by the stirrups,

D Diameter of circular columns,

$\mathrm{E}_{\mathrm{f}} \quad$ Modulus of elasticity of FRP,

$f_{c} \quad$ Compressive strength of concrete of the column,

$f_{c c} \quad$ Compressive strength of confined concrete,

$f_{c c, e} \quad$ Compressive strength of confined concrete with transverse reinforcement,

\section{Table 11}

Results of Student's t-test for columns strengthened with FRP and transverse reinforcement.

t-critical $=1.99897$

\begin{tabular}{|c|c|}
\hline References & $t$ \\
\hline Cusson and Paultre [2] and Samaan et al. [10] & -0.12386 \\
\hline Cusson and Paultre [2] and Miyauchi et al. [11] & -3.05512 \\
\hline Cusson and Paultre [2] and Kono et al. [12] & 5.66179 \\
\hline Cusson and Paultre [2] and Toutanji [13] & -4.95605 \\
\hline Cusson and Paultre [2] and Saafi et al. [14] & 1.58771 \\
\hline Cusson and Paultre [2] and Spoelstra and Monti [15] & 2.15434 \\
\hline Cusson and Paultre [2] and Fardis and Khalili [16] & 5.33989 \\
\hline Cusson and Paultre [2] and Karbahari and Eckel [17] & 2.77478 \\
\hline Cusson and Paultre [2] and Mirmiran and Shahawy [18] & 6.74943 \\
\hline $\begin{array}{c}\text { Cusson and Paultre [2] and Shehata, Carneiro } \\
\text { and Shehata [19] }\end{array}$ & 5.66797 \\
\hline Saatcioglu and Razvi [3] and Samaan et al. [10] & -2.85229 \\
\hline Saatcioglu and Razvi [3] and Miyauchi et al. [11] & -5.52444 \\
\hline Saatcioglu and Razvi [3] and Kono et al. [12] & 1.99897 \\
\hline Saatcioglu and Razvi [3] and Toutanji [13] & -6.67271 \\
\hline Saatcioglu and Razvi [3] and Saafi et al. [14] & -1.78451 \\
\hline Saatcioglu and Razvi [3] and Spoelstra and Monti [15] & -1.72622 \\
\hline Saatcioglu and Razvi [3] and Fardis and Khalili [16] & 0.73222 \\
\hline Saatcioglu and Razvi [3] and Karbahari and Eckel [17] & -0.96384 \\
\hline Saatcioglu and Razvi [3] and Mirmiran and Shahawy [18] & 2.56853 \\
\hline $\begin{array}{c}\text { Saatcioglu and Razvi [3] and Shehata, Carneiro } \\
\text { and Shehata [19] }\end{array}$ & 0.98920 \\
\hline Frangou et al. [4] and Samaan et al. [10] & 0.23657 \\
\hline Frangou et al. [4] and Miyauchi et al. [11] & -2.70569 \\
\hline Frangou et al. [4] and Kono et al. [12] & 6.19093 \\
\hline Frangou et al. [4] and Toutanji [13] & -4.71205 \\
\hline Frangou et al. [4] and Saafi et al. [14] & 2.02394 \\
\hline Frangou et al. [4] and Spoelstra and Monti [15] & 2.64534 \\
\hline Frangou et al. [4] and Fardis and Khalili [16] & 5.87421 \\
\hline Frangou et al. [4] and Karbahari and Eckel [17] & 3.24570 \\
\hline Frangou et al. [4] and Mirmiran and Shahawy [18] & 7.20314 \\
\hline Frangou et al. [4] and Shehata, Carneiro, and Shehata [19] & 6.20487 \\
\hline fib Model Code 2010 [5] and Samaan et al. [10] & -1.35751 \\
\hline fib Model Code 2010 [5] and Miyauchi et al. [11] & -4.28415 \\
\hline fib Model Code 2010 [5] and Kono et al. [12] & 3.95378 \\
\hline fib Model Code 2010 [5] and Toutanji [13] & -5.88707 \\
\hline fib Model Code 2010 [5] and Saafi et al. [14] & 0.13277 \\
\hline fib Model Code 2010 [5] and Spoelstra and Monti [15] & 0.48751 \\
\hline fib Model Code 2010 [5] and Fardis and Khalili [16] & 3.50500 \\
\hline fib Model Code 2010 [5] and Karbahari and Eckel [17] & 1.20664 \\
\hline fib Model Code 2010 [5] and Mirmiran and Shahawy [18] & 5.19730 \\
\hline $\begin{array}{c}\text { fib Model Code } 2010 \text { [5] and Shehata, Carneiro } \\
\text { and Shehata [19] }\end{array}$ & 3.81781 \\
\hline Machado [9] & -2.85789 \\
\hline
\end{tabular}

$f_{c c, e x p} \quad$ Experimental compressive strength of confined concrete,

$\mathrm{f}_{\mathrm{cc}, \mathrm{fxp}} \quad$ Compressive strength of confined concrete with RFP,

$\mathrm{f}_{\mathrm{f}} \quad$ Tensile strength of FRP,

$f_{1} \quad$ Lateral pressure,

$f_{\text {e }} \quad$ Nominal lateral pressure,

$f_{\text {le }} \quad$ Lateral pressure of transverse reinforcement,

$f_{\text {If }} \quad$ Lateral pressure of CFRP,

$f_{l, f(b)} \quad$ Lateral pressure applied on side $b$ of cross-section,

$f_{1, f(h)} \quad$ Lateral pressure applied on side $h$ of cross-section,

$f_{y, t} \quad$ Yield strength of transverse steel,

$\mathrm{f}_{\mathrm{y}, \mathrm{l}}^{\mathrm{y}, \mathrm{L}} \quad$ Yield strength of longitudinal steel,

FRP Fiber Reinforced Polymers,

$F_{u, e x p} \quad$ Experimental ultimate load of the column,

$F_{\text {utheor }} \quad$ Theoretical ultimate load of the column,

GFRP Glass Fiber Reinforced Polymers,

h Cross-section height of the rectangular column,

$\mathrm{H} \quad$ Column height,

$k_{a}, k_{b}, k_{2}, K_{e} \quad$ Coefficient of confinement effectiveness,

$n \quad$ Number of CFRP sheets,

$n^{0} \quad$ Number of longitudinal reinforcements,

$r^{\prime} \quad$ Ratio of the column dimensions,

s Center-to-center spacing between stirrups,

$s^{\prime} \quad$ Clear spacing of stirups,

$t_{f} \quad$ Thickness of the CFRP sheet,

w_i Clear spacing between adjacent longitudinal steel bars,

$\alpha \quad$ Level of significance for Student's t-test,

$\alpha_{n}, \alpha_{s}, \alpha^{\prime} \quad$ Reduction factor,

$\theta \quad$ Angle between the transverse reinforcement and $b_{c^{\prime}}$,

$\lambda \quad$ Slenderness index,

$\xi \quad$ CFRP deformation,

$\rho_{1} \quad$ Longitudinal reinforcement ratio in the core section,

$\rho_{\mathrm{t}} \quad$ Transverse reinforcement ratio in the core section,

$\phi_{1} \quad$ Longitudinal reinforcement diameter,

$\phi_{\mathrm{t}} \quad$ Transverse reinforcement diameter,

$\omega_{c}, \omega_{\mathrm{w}} \quad$ Confinement rate.

\section{References}

[1] TAKEUTI, A. R. Strengthening of reinforced concrete columns by means of high-performance concrete jacketing, 1999 - Escola de Engenharia de São Carlos, Universidade de São Carlos, 184 p. [in Portuguese]

[2] CUSSON, D., PAULTRE, P. Stress-strain model for confined high-strength concrete. Journal of Structural Engineering, ASCE, v. 121, n. 3, 1995, pp.. 468-477.

[3] SAATCIOGLU, M., RAZVI, S. R. Strength and ductility of confined concrete. Journal of Structural Engineering. ASCE. v. 118, n. 6,1992 , pp. 1590-1607.

[4] FRANGOU, M., PILAKOUTAS, K. DRITSOS, S. Structural repair/strengthening of RC columns. Construction and Building Materials, v. 9, n. 5, 1995, pp. 259-266.

[5] FIB: FÉDERATION INTERNATIONALE DU BETÓN. Model Code 2010 - Final draft, v. 2. Bulletin 66. 2012, pp. 16-26.

[6] CARRAZEDO, R. Confinement effects and their implication on the strengthening of concrete columns by wrapping with carbon fiber composites. São Paulo, 2002 - Escola de En- 
genharia de São Carlos, Universidade de São Carlos, 173 p. [in Portuguese]

[7] MANDER, J., PRIESTLEY, M., PARK, R. Theoretical stressstrain model for confined concrete. Journal of Structural Engineering, v. 114, n. 8, 1988, pp. 1804-1826.

[8] CEN: EUROPEAN COMMITTEE FOR STANDARDIZATION. Eurocode 8: Design of structures for earthquake resistance - Part 1: General rules, seismic action and rules for buildings, Brussels, 2003, $215 \mathrm{p}$.

[9] MACHADO, A. P. Reforço de Estruturas de Concreto Armado com Fibras de Carbono: Características, dimensionamento e aplicação. São Paulo: PINI, 1ed, 2002, 271 p. [in Portuguese]

[10] SAMAAN, M., MIRMIRAN, A., SHAHAWY, M. Model of concrete confined by fiber composites. Journal of Structural Engineering, v. 124, 1998, pp. 1025-1031.

[11] MIYAUCHI, K., NISHIBAYASHI, S., INOUE, S. Estimation of strengthening effects with carbon fiber sheet for concrete column. International Symposium. Tokyo, v. 1, 1997, pp. 217-225.

[12] KONO, S., INAZUMI, M., KAKU, T. Evaluation of confining effects of CFRP sheets on reinforced concrete members. Proceedings of the Second International on Composites in Infrastructure, ICCl '98, H. Saadatmanesh and M. R. Ehsani, Editors, Tucson, Arizona, 1998, pp. 343-355.

[13] TOUTANJI, H. A. Stress-strain characteristics of concrete columns externally confined with advanced fiber composite sheets. ACI Materials Journal, v. 96, n. 3, 1999, pp. 397-404.

[14] SAAFI, M., TOUTANJI, H.A., LI, Z. Behaviour of concrete columns confined with fiber reinforced polymer tubes. ACl Materials Journal, v. 96, n. 4, 1999, pp. 500-509.

[15] SPOELSTRA, M.R., MONTI, G. FRP-confined concrete model. Journal of Composites for Construction, v. 3, n. 3, 1999, pp. 143-150.

[16] FARDIS, M. N., KHALILI, H. H. Concrete encased in fiberglass-reinforced plastic. ACI Materials Journal, v. 78, n. 6, 1981, pp. 440-446.

[17] KARBHARI, V.M., ECKEL, D.A. Strengthening of concrete column stubs through resin infused composite wraps. Journal of Thermoplastic Composite Materials, v. 6, 1993, pp.
92-107.

[18] MIRMIRAN, A., SHAHAWY, M. Behavior of concrete columns confined with fiber composites. Journal of Structural Engineering, ASCE, v. 123, 1997, pp. 583-590.

[19] SHEHATA, I., CARNEIRO, L., SHEHATA, L. Strength of short concrete columns confined with CFRP sheets. Materials and Structures. v. 35, 2002, pp. 50-58.

[20] EID, R., ROY, N. PAULTRE, P. Normal- and high-strength concrete circular elements wrapped with FRP composites. Journal of Composites for Construction. v. 13, 2009, pp. 113-124.

[21] WANG, Z., WANG, D., SMITH, S. T., LU, D. Experimental testing and analytical modeling of CFRP-confined large circular RC columns subjected to cyclic axial compression. Engineering Structures. v. 40, 2012, pp. 64-74.

[22] LEE, J. Y., OH, Y. J., PARK, J. S., MANSOUR, M. Y. Behaviors of concrete columns confined with both spiral and fiber composites. In: 13th World Conference on Earthquake Engineering, 2004, Vancouver, Canada.

[23] HUANG, L., SUN, X., YAN, L., ZHU, D. Compressive behavior of concrete confined with GFRP tubes and steel spirals. Polymers, 7, 2015, pp. 851-875.

[24] YIN, P., HUANG, L., YAN, L., ZHU, D. Compressive behavior of concrete confined by CFRP and transverse spiral reinforcement. Part A: Experimental study. Materials and Structures, v. 49, n. 3, 2016, pp. 1001-1011.

[25] MONTGOMERY, D. C., RUNGER, G. C. Estatística Aplicada e Probabilidade para Engenheiros. Rio de Janeiro: LTC, 4 ed, 2003, 464 p. [in Portuguese]

\section{Table 12}

Design models with the best predictions of column strengthening

\begin{tabular}{crcc}
\hline Comb. & References & Mean & CV \\
\hline 1 & Cusson and Paultre [2] and Samaan et al. [10] & 0.97 & 0.22 \\
5 & Cusson and Paultre [2] and Saafi et al. [14] & 0.93 & 0.22 \\
13 & Saatcioglu and Razvi [3] and Kono et al. [12] & 0.93 & 0.24 \\
17 & Saatcioglu and Razvi [3] and Fardis and Khalili [16] & 0.95 & 0.22 \\
18 & Saatcioglu and Razvi [3] and Karbhari and Eckel [17] & 1.00 & 0.22 \\
20 & Saatcioglu and Razvi [3] and Shehata, Carneiro, and Shehata [19] & 0.95 & 0.22 \\
21 & Frangou et al. [4] and Samaan et al. [10] & 0.96 & 0.22 \\
31 & fib Model Code 2010 [5] and Samaan et al. [10] & 1.00 & 0.21 \\
35 & fib Model Code 2010 [5] and Saafi et al. [14] & 0.97 & 0.21 \\
36 & fib Model Code 2010 [5] and Spoelstra and Monti [15] & 0.97 & 0.20 \\
38 & fib Model Code 2010 [5] and Karbhari and Eckel [17] & 0.94 & 0.21 \\
\hline
\end{tabular}




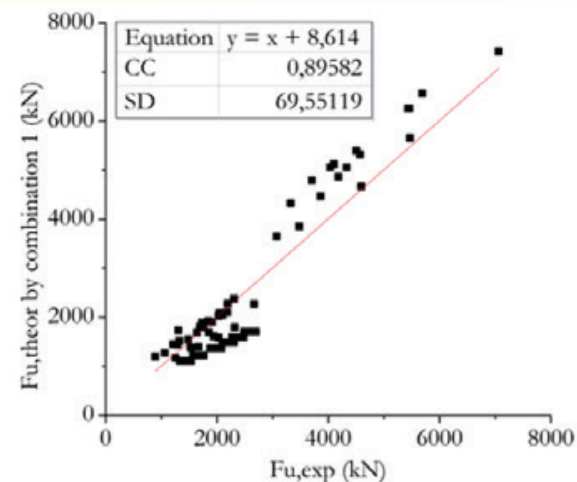

(a)

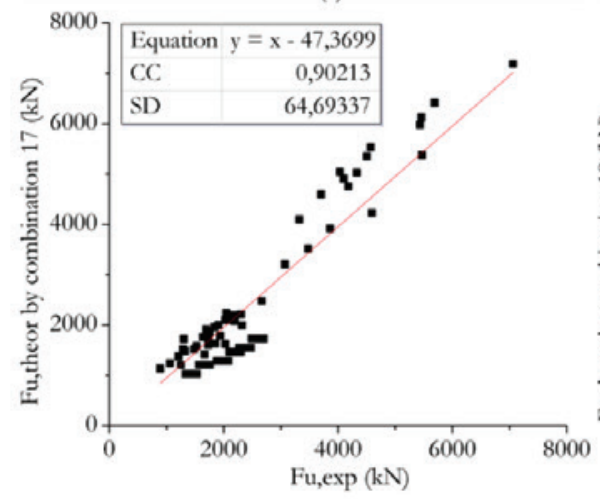

(d)

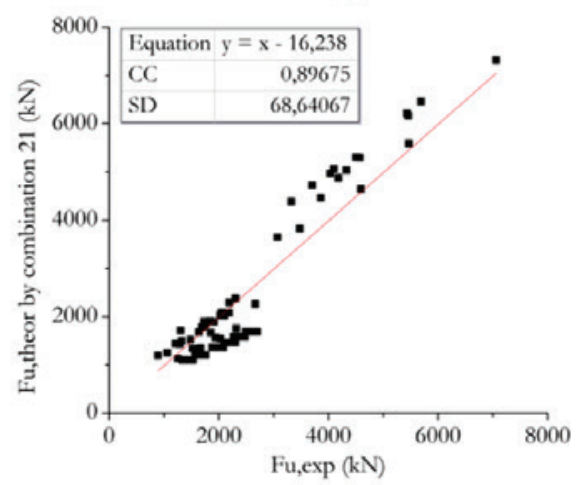

(g)

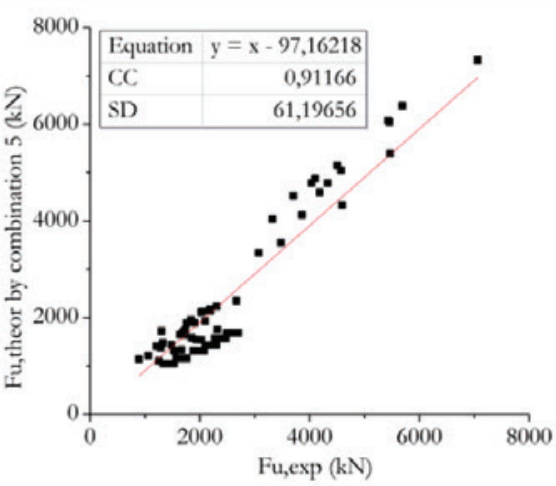

(b)

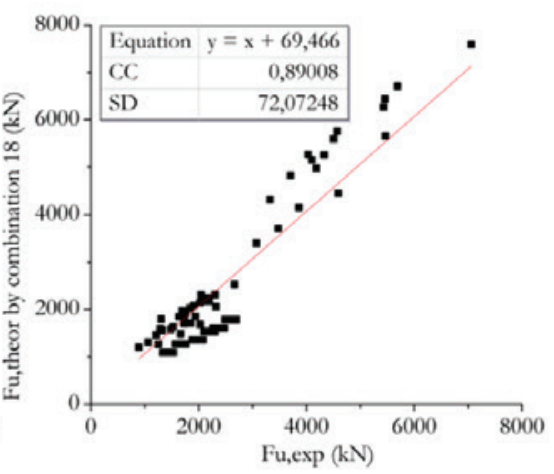

(e)

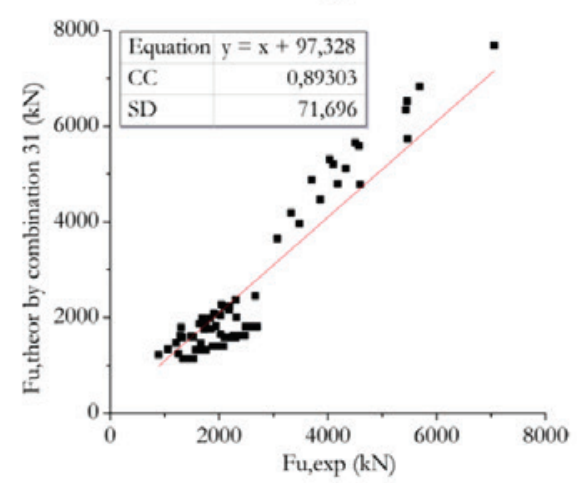

(h)

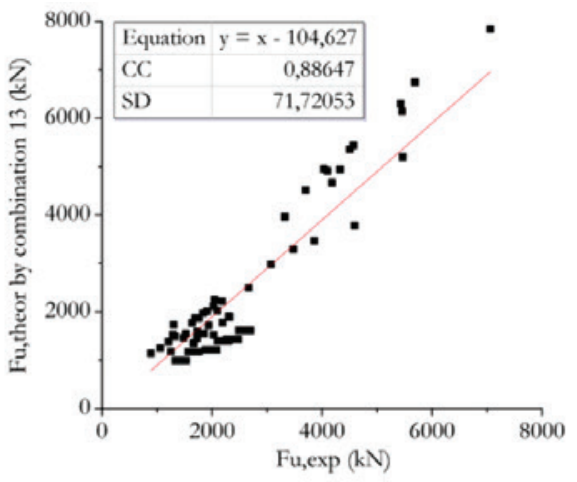

(c)

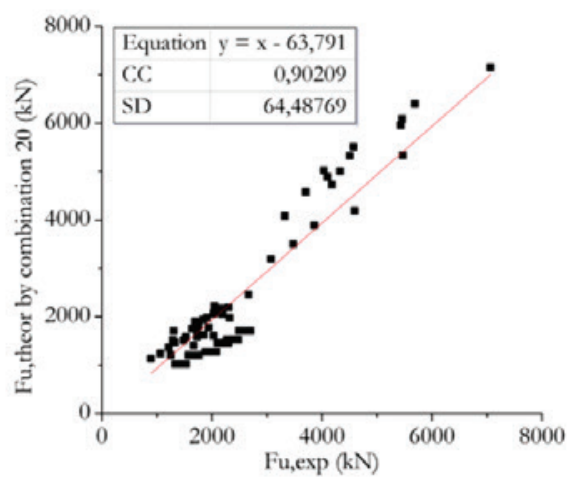

(f)

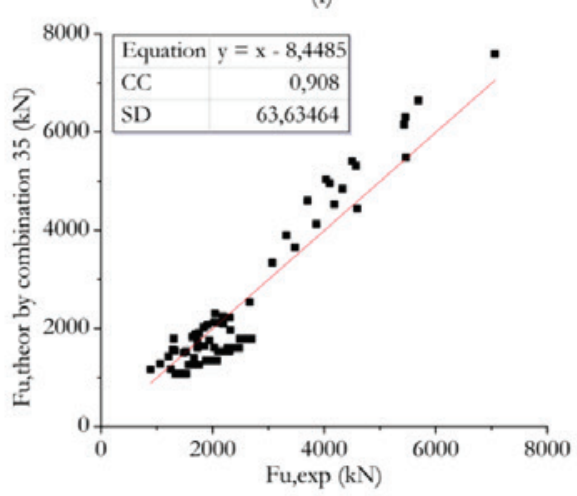

(i)

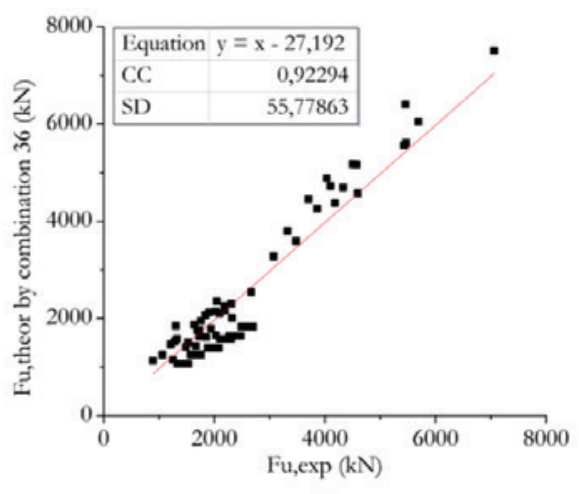

(j)

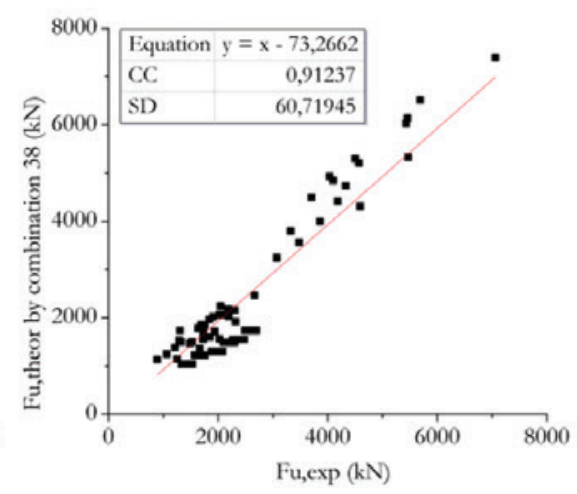

(k)

\section{Figure 11}

Comparison of theoretical and experimental results of ultimate load of the column $\left(F_{\text {RuR }}\right)$ strengthened with FRP and transverse reinforcement. (a) Combination 1; (b) Combination 5; (c) Combination 13; (d) Combination 17; (e) Combination 18; (f) Combination 20; (g) Combination 21; (h) Combination 31; (i) Combination 35; (j) Combination 36; (k) Combination 38. CC: Correlation coefficient; SD: Standard deviation. 